\title{
Alcohol Addiction: A Molecular Biology Perspective
}

\author{
Giampiero Ferraguti ${ }^{1}$, Esterina Pascale ${ }^{2}$ and Marco Lucarelli ${ }^{1,3,4, *}$
}

${ }^{I}$ Dept. of Cellular Biotechnologies and Hematology, Sapienza University of Rome, Italy; ${ }^{2}$ Dept. of MedicalSurgical Sciences and Biotechnologies, Sapienza University of Rome, Italy; ${ }^{3}$ Pasteur Institute - Cenci Bolognetti Foundation, Sapienza University of Rome, Italy; ${ }^{4}$ Policlinico Umberto I Hospital, Rome, Italy

\begin{abstract}
Alcohol misuse represents worldwide an important risk factor for death and disability. Excessive alcohol consumption is widely diffused in different ethnicities and alcohol use is part of the lifestyle of both young and old people. The genetic basis of alcohol dependence concerning ethanol metabolism and the pathways of reward circuits are well known. The role of genetic variants in the neurobiology of addiction as well as in response to medication in alcoholism therapy still represents an intriguing argument that needs to be deeply analyzed and explained. The molecular approach to the study of these aspects could be difficult because of the large number of genes and variations involved. Our work is intended to offer an overview of genes and variants involved in alcohol addiction and pharmacogenetics. Our aim is to delineate a molecular approach strategy to look at alcohol dependence from a genetic and applicative point of view. The indications provided in this work should be of help for those who wish to undertake a molecular study of this multifactorial disease.
\end{abstract}

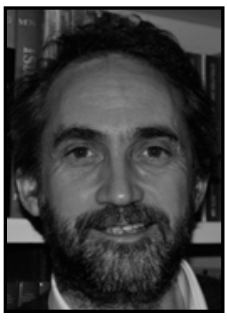

Keywords: Alcohol addiction, genetic variants, neurobiology, pharmacogenetics, SNPs, therapy.

\section{INTRODUCTION}

Alcohol misuse is universally considered a huge problem. Excessive alcohol consumption is widely diffused in different ethnicities, from young to old people, and represents an important risk factor for death and disability. In the recently revised Diagnostic and Statistical Manual of Mental Disorders [1], a single category of alcohol use disorders (AUD) is now present instead of alcohol abuse and alcohol dependence (AD) which were considered separately. Processes involved in AUD are located mainly in the brain and depend upon complex interactions between genes and the environment. As shown in many studies that have taken into consideration families, twins and adoptive sons, the genetic component accounts for at least $60 \%$ of the risk factors [2-4] and also the quantity of alcohol consumed, frequency of drinking, risk of toxicity as well as the response to medication seems to be genetically controlled. Nowadays molecular genetics studies are focalized on biochemical pathways of neuronal circuits of reward, addiction and satisfaction in addition to studies on biochemical pathways of alcohol metabolism. These latter are of great importance not only for alcohol dependence but also for tumorigenesis mediated by intermediate products of alcohol metabolism [5] and for risk of myocardial infarction and of coronary artery disease [6]. The tuning of neurocognitive, behavioral and psychosocial aspects of alcohol abuse has led us to pay closer attention to new candidate genes that rule alcohol susceptibility and response to pharmacological treatment. As examples, the $\mu$

\footnotetext{
*Address correspondence to this author at the Dipartimento di Biotecnologie Cellulari ed Ematologia, Sapienza Università di Roma, c/o Azienda Policlinico Umberto I, Edificio 33, I piano. Viale Regina Elena 324, 00161. Roma, Italia; Tel/Fax: +39-06-4451784;

E-mail: marco.lucarelli@uniroma1.it
}

opioid receptor gene (Oprm1), that encodes for the $\mu$ opioid receptor, is involved in reward and emotional pathways and in the pharmacological response to the receptor antagonist naltrexone. The solute carrier family 6 member 4 (Slc6a4) gene, encoding for the serotonin transporter, is the molecular target of many antidepressants (serotonin reuptake inhibitors) and is also linked to major depressive disorders. Gamma-aminobutyric acid receptor ( $G a b r)$ genes, that encode for the subunits of the GABA (gamma-aminobutyric acid) receptor, are strongly associated with severe alcohol addiction. Alcohol compromises also glutamatergic transmission by affecting the functions of ionotropic and of metabotropic glutamate receptors. Solute carrier family $6 \mathrm{mem}-$ ber 3 (Slc6a3) (dopamine transporter), dopamine receptor D2 $(\operatorname{Drd} 2)$ and dopamine receptor D4 $(D r d 4)$ genes, that regulate the release and synthesis of dopamine, have strong effects on mechanisms of reward that correlate with alcohol consumption. All these genes affect neurobiology of cognitive functions, anxiety, depression, reward and neuronal plasticity in response to alcohol administration. A large number of association studies are ongoing to consolidate data and provide new molecular markers of dependence in order to define genotype-phenotype relationships and personal therapeutic strategies. The sequence variations involved are, in most cases, single nucleotide polymorphisms (SNPs) whereas, in other cases, are a variable number of tandem repeats (VNTR) that could confer susceptibility or protection in response to alcohol administration. Genome wide association studies (GWAS) together with candidate gene approaches have already delineated a large number of molecular targets possibly related to a genetic predisposition to alcohol abuse and addiction [7]. GWAS focusing on this argument will be reviewed later on this paper as well as pros and cons related to this powerful approach. The comparison 
between a target and a matched control population, for a single or a set of DNA sequence variations, provides robust information about the relevance of the variations analyzed. More powerful information can be retrieved if a correct layering of patients is done, especially for alcoholism where behavioral, social and biological features are contemporarily involved. Unfortunately, the usefulness of these approaches is often limited by the small size of case series and by the consequent reduced power of statistical approaches.

The biological aspects of alcohol addiction are extremely various, here we describe genetic variants that concern the genes involved in metabolizing alcohol pathways as well as those involved in neural transmission and implicated in the pathogenesis and treatment of alcoholism. This paper is intended to offer an overview of those sequence variations involved in alcohol addiction mechanisms, with the aim to delineate a molecular approach strategy to look at alcohol dependence from a genetic and applicative point of view. The indications provided should be of help for those who wish to undertake a molecular study of this multifactorial disease.

\section{MOLECULAR BIOLOGY OF ALCOHOL METABO- LIZING ENZYMES}

The liver metabolizes circulating alcohol mainly in two successive steps: alcohol dehydrogenase (ADH) catalyzes the reversible oxidation of ethanol to acetaldehyde and aldehyde dehydrogenase (ALDH) transforms the acetaldehyde produced in acetic acid.

The following paragraphs use the new nomenclature for the human alcohol dehydrogenase as described in the work of Duester and colleagues [8].

In Table 1 the organization and the characteristics of the genes related to alcohol metabolizing enzymes, are shown. In Table 2 a concise list of all point variations described in the sections below is provided.

\section{Alcohol Dehydrogenase (ADH)}

Alcohol dehydrogenase is a member of the MDR (Medium chain reductase/dehydrogenase) family of proteins. Five different classes of ADH exist in humans. This protein, formed by two subunits, can exist as a homo- or heterodimer. Seven different genes cluster in the chromosome $4 \mathrm{q}$ region and code for the monomers. The class $\mathrm{I} A D H$ is mainly involved in alcohol metabolism of humans. Subunits named $\alpha, \beta$ e $\gamma$, which share more than $93 \%$ of sequence homology [9], combine to form homo- and hetero-dimers and are encoded respectively by Adhla, Adhlb and Adhlc genes. Sequence variations of $A d h 1 b$ produce three different subunits: $\beta 1, \beta 2$ and $\beta 3$. Two polymorphisms occurring respectively at position 48 (p.Arg48His - rs1229984) and at position 370 (p.Arg370Cys - rs2066702) of the polypeptide chain of the $\beta$ subunit, define the $A d h 1 b * 1$ (48Arg-370Arg), *2 (48His-370Arg) or *3 (48Arg-370Cys) allele. The genotypes $A d h 1 b * 1 / A d h 1 b * 2(\beta 1 / \beta 2)$ and the $A d h 1 b * 2 / A d h 1 b * 2$ $(\beta 2 / \beta 2)$ produce an enzyme up to 100 times faster than the $A d h 1 b * 1 / A d h 1 b * 1(\beta 1 / \beta 1)$ genotype [10]. These well-known risk loci were recently confirmed in the largest sample for AD GWAS to date by Gelernter et al [11]. Adh1b*2 allele was found to be protective in association with Aldh2 Lys504 allele (p.Glu504Lys - rs671) in a Korean population of 1032 individuals [12]. The presence of both the alleles Arg48 and Glu504 confers a greater susceptibility for AD if compared to the presence of one or none of the risk alleles. In a recent GWAS performed in a large sample of Korean AD subjects, Park and colleagues found that the Adh1b rs1229984 polymorphism has a significant association with $\mathrm{AD}$ (with the Arg48 as the risk allele) and that this variation could be the only functional genetic marker in the ADH gene cluster [13]. The $A d h 1 b * 3$ allele was found mainly in African lineage population [14]. This polymorphic allele seems to have a protective role with a reduced risk for alcohol dependence [15-17]. Higher level of sedation in $A d h 1 b * 3$ carriers after alcohol administration [18] or, as otherwise supposed, the faster elimination of ethanol that leads to higher levels of acetaldehyde are responsible for adverse effects after alcohol consumption. The subunit $\beta 1\left(A d h 1 b^{*} 1\right)$ carrying no variation at both sites results in a wild type protein. Adhlc give rise to $A d h 1 c * 1$ and $A d h 1 c * 2$ subunits depending on two polymorphic sites, one in exon 6 (p.Arg272Gln; rs1693482) and the other in exon 8 (p.Ile350Val; rs698). Adh1 $c^{* 1}$ and $A d h 1 c * 2$ represent two different haplotypes, 272Arg-350Ile and $272 \mathrm{Gln}-350 \mathrm{Val}$ respectively, arising from the above mentioned polymorphisms which are known to be in strong linkage [18]. The Adhlc*l variant in homozygosis was described as protective about alcohol addiction if compared to $A d h 1 c * 2$, heterozygotes and homozygotes, in Asian populations $[19,20]$. The $A d h 1 c * 2$ variant shows a slight association with alcohol dependence in European populations; this may be due to a linkage of this variation with $A d h 1 b$ in some ethnic groups [21]. Class II ADH, as well as class III, only exists as a homodimer. Class II alcohol dehydrogenase contributes to alcohol metabolism in the liver at high concentration, its role in alcoholism is still under investigation. Many polymorphisms of the $A d h 2$ gene seems to be involved in alcohol dependence [15,22-24] but with divergent results in different populations. The c.-136A $>C$ (rs 1800759) in the promoter region of $A d h 2$ gene seems to be the most interesting among sequence variations studied with the $\mathrm{C}$ allele associated with a lower activity of the $\pi$ subunit. Another SNP (rs1042364) occurring at exon 9 causes an aminoacid substitution (p.Gly388Arg) that might also affect the function of the $\pi$ subunit. Results from large multicenter association studies confirm the significant relationship of Adh2 variants with an AD phenotype. The effect is of a predisposition to AD that explicates itself in a recessive manner and in specific populations, but with a lower impact if compared with functional variants of other alcohol or acetaldehydemetabolizing enzymes [23,24]. The remaining ADH classes seem not to be involved in alcohol use disorders.

\section{Aldehyde Dehydrogenase (ALDH)}

The human genome contains 19 Aldh genes whose products participate in oxidizing a large number of endogenous and exogenous aldehydes. Aldhlal, which is in the cytosol, and mitochondrial Aldh2, mainly contribute to the metabolism of acetaldehyde in vivo. The Aldh2 gene has a polymorphic locus on exon 12 that causes an amino acid change from glutamic acid to lysine at the $504^{\text {th }}$ position of the polypeptide chain (p.Glu504Lys - rs671) due to a G to A change in the nucleotidic sequence. The A allele $(A l d h 2 * 2)$ encodes an inactive subunit with an impaired ability to metabolize acetaldehyde. 
Table 1. Organization and characteristics of genes related to alcohol metabolizing enzymes involved in alcohol dependence.

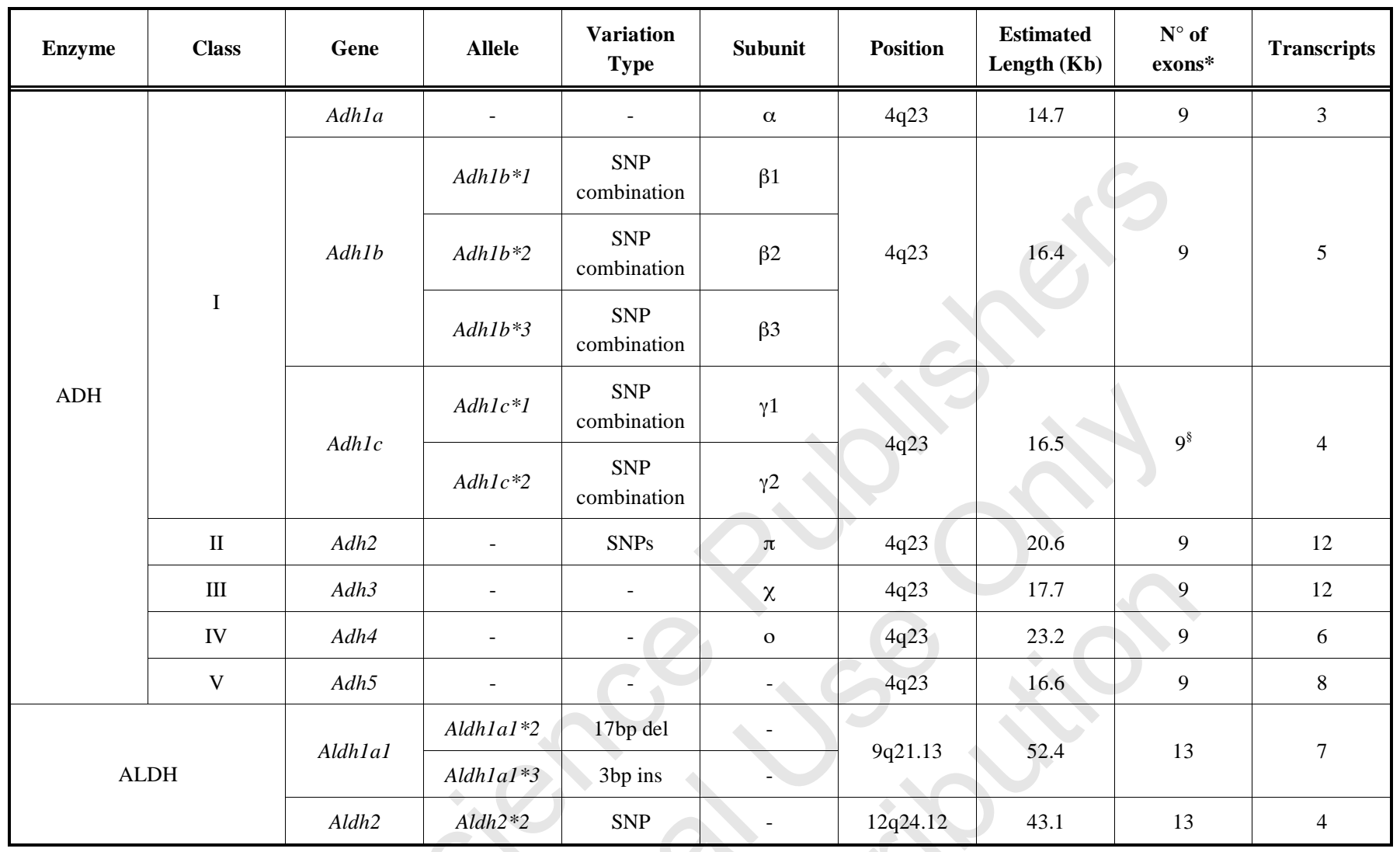

*The number of exons and the estimated length are referred to the longest transcript of the single gene registered in the Consensus CDS project (or to the longest transcript if no Consensus CDS registered sequence is available).

${ }^{\S}$ no Consensus CDS sequence available.

Table 2. Single nucleotide polymorphisms of genes related to alcohol metabolizing enzymes involved in alcohol dependence.

\begin{tabular}{|c|c|c|c|c|}
\hline Gene & rs/HGMD Accession & $\begin{array}{l}\text { Nucleotide Change } \\
\text { (Forward Strand) }\end{array}$ & $\begin{array}{c}\text { Aminoacid Change } \\
\text { (Codon) }\end{array}$ & $\begin{array}{c}\text { Allelic Frequencies } \\
\text { (Overall, } 1000 \text { Genomes) }\end{array}$ \\
\hline \multirow{2}{*}{$A d h 1 b$} & rs1229984 & $\mathrm{T} / \mathrm{C}$ & p.Arg48His & $\mathrm{T}(0.21) / \mathrm{C}(0.79)$ \\
\hline & rs 2066702 & $\mathrm{G} / \mathrm{A}$ & p.Arg370Cys & $\mathrm{G}(0.95) / \mathrm{A}(0.05)$ \\
\hline Adhlc & rs 1693482 & $\mathrm{C} / \mathrm{T}$ & p.Arg $272 \mathrm{Gln}$ & $\mathrm{C}(0.76) / \mathrm{T}(0.24)$ \\
\hline \multirow{2}{*}{$A d h 2$} & rs1800759 & $\mathrm{T} / \mathrm{G}$ & n. c. & $\mathrm{T}(0.46) / \mathrm{G}(0.54)$ \\
\hline & rs 1042364 & $\mathrm{~T} / \mathrm{C}$ & n. c. & $\mathrm{T}(0.14) / \mathrm{C}(0.86)$ \\
\hline Aldh2 & rs671 & $\mathrm{G} / \mathrm{A}$ & p.Glu504Lys & $\mathrm{G}(0.94) / \mathrm{A}(0.06)$ \\
\hline
\end{tabular}

n. $c .=$ no change

Several polymorphic variants have been identified in the promoter region of the Aldhlal gene: a 17-bp deletion $($ Aldhla1*2) and a 3-bp insertion (Aldhla1*3), even though the effect of Aldhlal variants on alcohol metabolism and alcohol response is still unclear [18,25]. Aldh variants affecting the enzyme function may result in a protective effect for alcohol dependence and heavy drinking due to a less efficient breakdown of acetaldehyde and a stronger response to alcohol that include the adverse effect of the "flushing reaction'. An increased production or an impaired metabolism of acetaldehyde produces flushes and blotches associated with erythema that appear on the face, neck, shoulders and sometimes on the entire body, of individuals that consume alcohol because of an accumulation of this toxic product. Subjects experiencing the alcohol flush reaction are less prone to alcohol addiction (Fig. 1). 


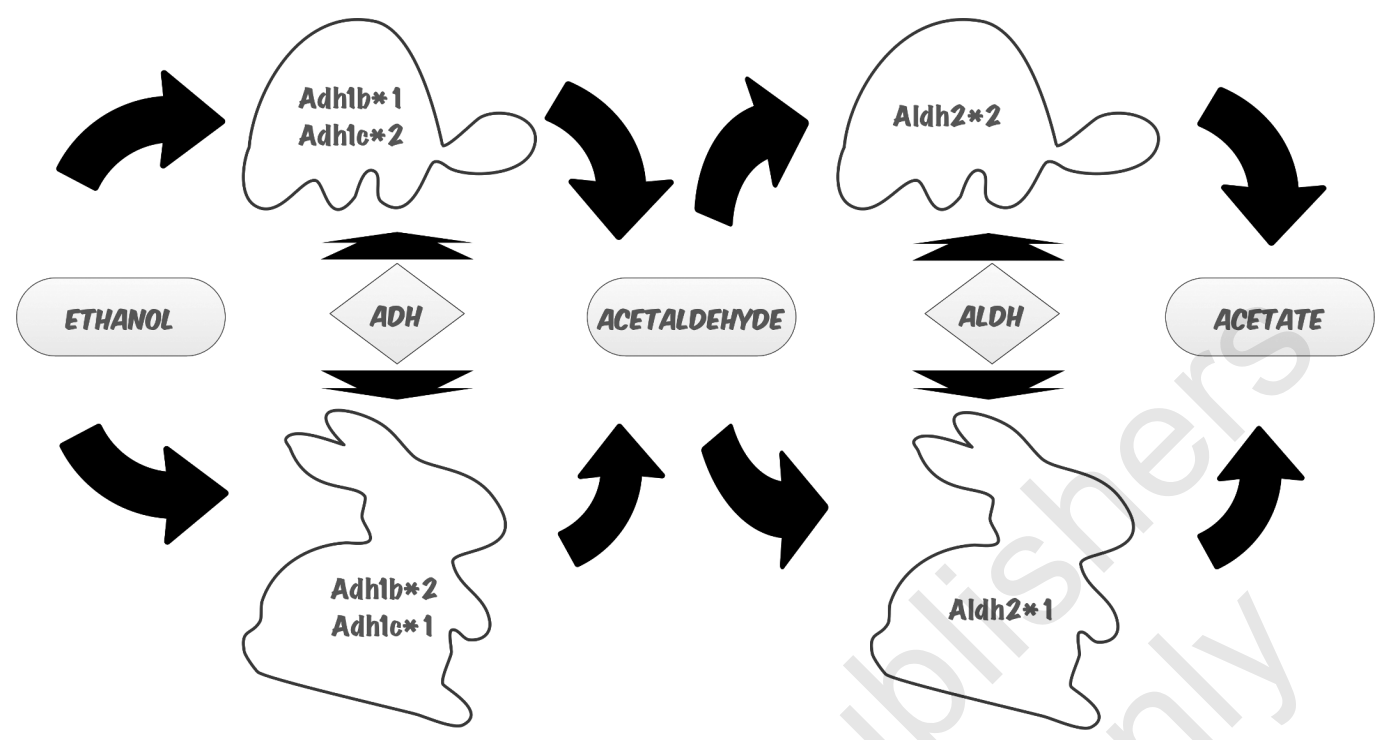

Fig. (1). The presence of different alleles that code for subunits of alcohol metabolizing enzymes determines the efficiency of trasformation of alcohol and acetaldehyde. As a result, an increased production or an impaired metabolism of acetaldehyde produces a "flushing reaction" that makes less prone to alcohol consumption. On the other hand, a rapid removal of ethanol and acetaldehyde could instead confer susceptibility to $\mathrm{AD}$. $\mathrm{ADH}=$ Alcohol dehydrogenase; $\mathrm{ALDH}=$ Aldehyde dehydrogenase; Rabbit= Higher efficiency; Turtle= Lower efficiency .

\section{MOLECULAR NEUROBIOLOGY OF ALCOHOL USE DISORDERS}

In Table 3 the characteristics of genes related to neurobiology of alcohol addiction, are summarized. In Table $\mathbf{4}$ and Table 5 a concise list of all point variations and VNTR described in the following paragraphs is provided.

\section{5-Hydroxytryptamine Transporter and Receptors}

Serotonin (5-hydroxytryptamine, 5-HT) has a primary role in different functions of the central nervous system, in health and disease. Depression, bipolar disorders, anxiety, obsessive - compulsive disorders, eating behavior, neurodegenerative disorders and drug addiction depend on serotonin trafficking within the brain [26]. Serotonin transport in the brain and in specific tissues such as cells and platelets is mediated by the serotonin transporter (5-HTT). In the synaptic space 5-HTT controls the rapid removal of 5-HT managing amplitude, length and spatial distribution of signals that reach serotonin receptors [27]. Changes in serotonin transmission are also associated with alcohol dependence [28]. Some studies have evidenced that an increase in serotonin transmission obtained by blocking 5-HT reuptake with selective serotonin re-uptake inhibitors (SSRIs), causes a reduction of alcohol consumption in various animal models [29]. In humans, however, lower brain levels of serotonin correlate with an augmented use of alcohol [30]. Due to its centrality in serotonin transmission, genetic studies concerning 5-HT function in alcohol dependence are focused on the Slc6a4 gene that codes for 5-HTT [31,32]. Transcriptional activity of this gene is modulated by a repeated element of variable length in the 5' flanking region, about $1.4 \mathrm{~kb}$ upstream from the transcription starting site called 5-HTTLPR (serotonin-transporter-linked polymorphic region). The $\mathrm{S}$ (Short) allele is made of 14 repeated elements (each repeated element is 20 or 23 nucleotides long), while the L (Long) allele is of 16 repeats. Alleles of $15,18,20$ or 22 repeats are less frequently observed. This functional polymorphism has been intensively investigated in relation to alcohol addiction and even though allelic and genotypic distribution is extremely variable among different ethnic groups, a recent meta-analysis demonstrates a significant but modest association between alcohol dependence and the presence of at least 1 short allele [33]. In healthy humans the L/L genotype have an increased 5-HT uptake in platelets and a greater brain serotonin binding. Expression analysis performed on human lymphoblastoid cells also show that 5-HTT mRNA levels are higher in L/L than in L/S or S/S genotypes. Alcohol dependent subjects with $\mathrm{L} / \mathrm{L}$ variants, compared with healthy individuals have, on the contrary, reduced $\left[{ }^{123} \mathrm{I}\right] 2 \beta$ carboxymethoxy-3 $\beta$-(4-iodophenyl)tropane ( $\beta$-CIT) neuronal binding to 5-HTTs in the raphe nuclei of the brain and a lower 5-HT uptake in platelets if compared with S/S genotype individuals [34]. A SNP in the 3'-untranslated region (3'-UTR) of the Slc6a4 gene, the rs1042173, was recently associated to severity of drinking [35] and to response to 5HT targeting therapy in AD patients. Another functional allelic variant (rs25531) in the 5'UTR region of the Slc6a4 gene, a few bases upstream from the regulatory 5HTTLPR region, can also modulate expression of the serotonin transporter. The presence of the $\mathrm{G}$ allele $(26247 \mathrm{~A}>\mathrm{G})$ makes the $\mathrm{L}$ allele as efficient as the lower-activity $\mathrm{S}$ allele [36]. These two polymorphic regions are commonly described together as a tri-allelic polymorphism, with the $\mathrm{L}_{\mathrm{A}}$ as the "high" expressing allele and both the $\mathrm{L}_{\mathrm{G}}$ and $\mathrm{S}$ as the "low" expressing alleles. In a recent work, Seneviratne and collaborators [37] showed that interactive effects of multiple sequence variations within the single pathway of serotoninergic transmission at different levels can confer greater susceptibility to alcohol dependence than the single variations considered alone. They found in alcoholic patients of European descent significant interactive effects among variants in the Slc6a4, $H t r 3 a$ and $H t r 3 b$ genes that encode respectively for the 5-HT $3 \mathrm{~A}$ and $3 \mathrm{~B}$ receptors. The low frequency allele of the SNP rs33940208 (T) in Htr3a and of the SNP rs2276305 (A) in $\mathrm{Htr} 3 \mathrm{~b}$ result inversely associated with AD. 
Table 3. Characteristics of genes related to neurobiology of alcohol dependence.

\begin{tabular}{|c|c|c|c|c|}
\hline Slc6a4 & $17 \mathrm{q} 11.2$ & 41.7 & 14 & 5 \\
\hline$H t r 3 a$ & $11 \mathrm{q} 23.2$ & 15.2 & 8 & 8 \\
\hline$H t r 3 b$ & $11 \mathrm{q} 23.2$ & 41.9 & 9 & 3 \\
\hline $\operatorname{Drd} 2$ & $11 \mathrm{q} 23.2$ & 65.8 & 8 & 11 \\
\hline Drdl & $5 q 35.2$ & 4.2 & 2 & 1 \\
\hline Comt & $22 \mathrm{q} 11.21$ & 28.4 & 6 & 11 \\
\hline Auts 2 & $7 \mathrm{q} 11.22$ & 1190 & 19 & 18 \\
\hline Chrm 2 & $7 q 33$ & 151.6 & 3 & 9 \\
\hline Chrna3 & $15 \mathrm{q} 25.1$ & 25.9 & 6 & 8 \\
\hline Chrna5 & $15 \mathrm{q} 25.1$ & 29.7 & 6 & 4 \\
\hline
\end{tabular}

*The number of exons and the estimated length are referred to the longest transcript of the single gene registered in the Consensus CDS project (or to the longest transcript if no Consensus CDS registered sequence is available).

\section{Dopamine Receptors and Transporter}

The dopaminergic system is deeply involved in brain reward circuits and plays an important role in alcohol-related behaviors. Neurochemical studies in animal models suggest that alcohol administration raises dopamine levels in nucleus accumbens and increases neurotransmission in dopaminergic neurons of the ventral tegmental area [38-40]. A decreased density in striatal dopamine receptors, observed in alcohol dependence, is supposed to decrease susceptibility to endogenous effectors of the reward circuits, pushing to alcohol abuse in order to compensate this lack of rewarding effect [41]. Among the components of the dopaminergic systems, the D2 dopamine receptor gene (Drd2) has been studied in depth in alcohol dependent subjects. The $\operatorname{Drd} 2$ gene has two polymorphic alleles that differ according to the presence or absence of a restriction site for the TaqI endonuclease (rs1800497). The TaqI polymorphism, that was supposed to be in the 3' non coding region of $\mathrm{Drd} 2$ gene, was found to be instead in the coding region of a neighbor gene, the Ankkl (ANKyrin repeat and Kinase domain containing 1) [42]. A large number of studies have focused on the relation between the Drd2/Ankk1 polymorphism (rs1800497) and alcohol dependence with different results. A meta-analysis performed by Lesley Smith and colleagues [43] reports a small effect for the association of the A1 allele (T), even though a strong association remains in studies that use ethnic-matched controls, or controls screened for alcohol dependency. A strong association was recently confirmed in a study conducted in 280 alcoholic subjects and 280 age- and sex-matched controls from central Italy [44]. The D4 receptor has been stud- ied as well in relation to alcohol abuse and addiction. Many studies have analyzed the exon 3 region of the $\operatorname{Drd} 4$ gene, where a VNTR of 48 base pairs affects dopamine transmission. Drd4 VNTR spans from 2 to 11: the longest alleles, 7 repeats or more, were recently associated in different studies with social drinking behavior, but with controversial results. A specific haplotype rs686 $\mathrm{T}$ allele and $\mathrm{rs} 4532 \mathrm{G}$ allele within the Drd1 gene is significantly more frequent in patients with alcohol dependence, with the T allele of rs686 largely frequent in patients with severe dependence and even more in subjects complicated by withdrawal seizures [45].

Dopamine transporter is a sodium/chloride dependent transporter, with 12 trans membrane domains, responsible for the dopamine reuptake in presynaptic neurons [46]. Dopamine transporter is encoded by the Slc6a3 gene. The coding region of this gene is strongly preserved and the polymorphisms found in this area are represented by synonymous base changes or sporadic irrelevant amino acid substitutions. The genetic polymorphism mainly studied in relation to alcohol dependence is a VNTR of $40 \mathrm{bp}$ in the 3' untranslated region of the Slc6a3 gene, with a number of repetitions that spans from 3 to 16 . Several studies have described this polymorphism in relation to $\mathrm{AD}$ with controversial results. With the intent to clarify the role of the dopamine transporter in alcohol addiction two meta-analysis on this argument have been recently published. The one by Du and colleagues investigated the association between the nine repetition allele of Slc6a3 and alcoholism, suggesting a possible association with a specific subset of patients with alcohol withdrawal 
Table 4. Single nucleotide polymorphisms associated with the neurobiology of alcohol dependence.

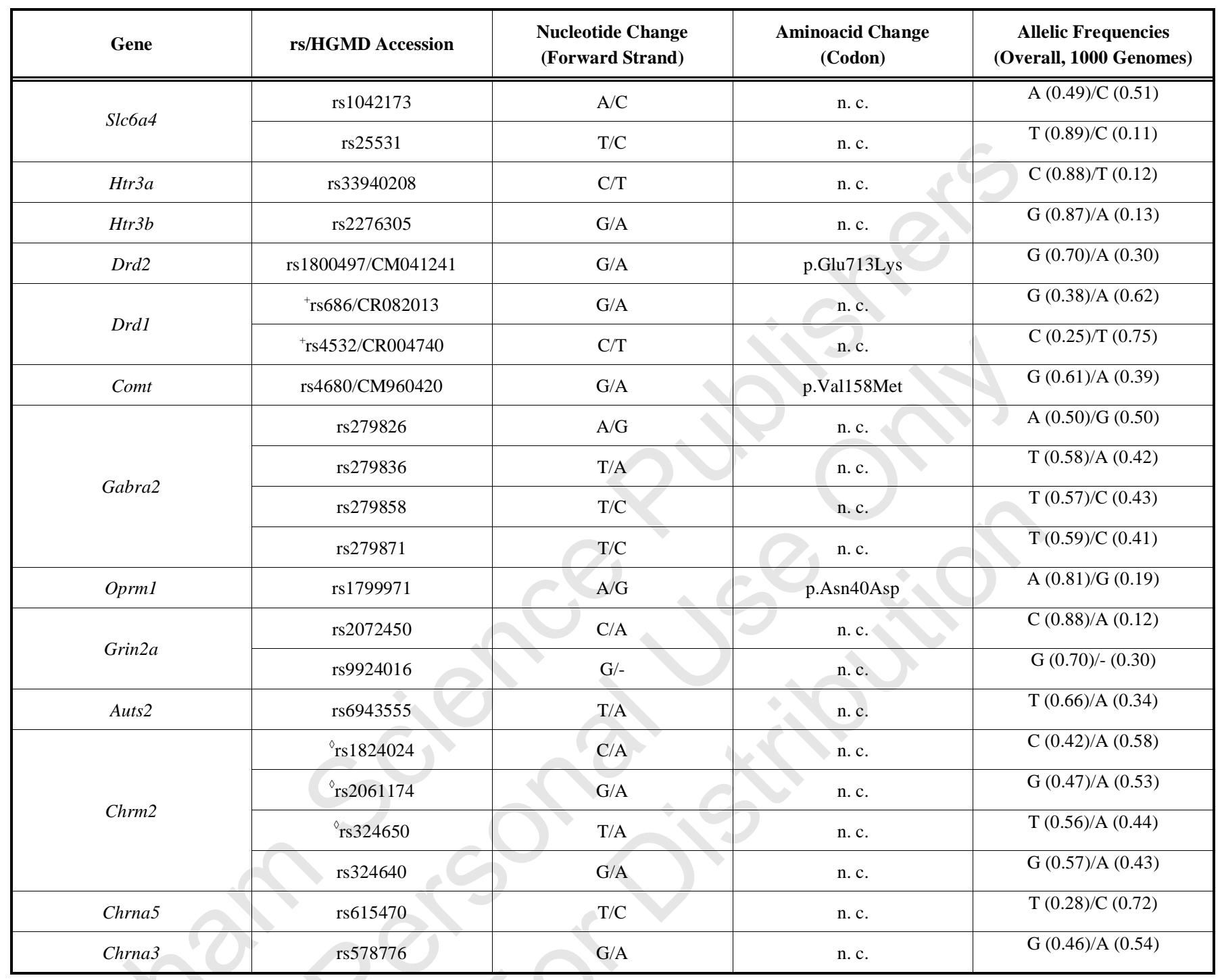

+rs686 (T) - rs4532 (G) specific haplotype is associated with alcohol dependence - ${ }^{8}$ the rare rs1824024 (G) - rs2061174 (T) - rs324650 (A) haplotype, was found to be overtransmitted to alcohol dependent individual; n. c.= no change

seizure or delirium tremens [47]. No association was found (in general or in stratified analysis according to the geographic area, ethnicity, gender, and diagnostic criteria) in a pooled analysis of published multicenter case-control studies, concerning the association between Slc6a3 polymorphism and alcohol dependence, performed by $\mathrm{Xu}$ and Lin [48]. This loss of association was recently confirmed in a case-control study performed by Mignini and colleagues on a population of central Italy [44]. Lastly, concerning the removal and metabolism of dopamine, several studies have shown that a missense mutation (p.Val158Met; rs4680) with a functional effect of the catechol-O-methyltransferase (Comt) gene is associated with alcohol dependence in men [49] and women with smoking comorbidity [50]. However, a larger sample analysis by Foroud and colleagues [51] failed to replicate this association. A more recent work [41] confirms this lack of association between Comt p.Val158Met genotype and alcohol dependence, but suggests that this variation, affecting dopamine receptor sensitivity at the level of the pre frontal cortex, can increase vulnerability to the development of alcohol dependence.

Table 5. VNTRs associated with the neurobiology of alcohol dependence.

\begin{tabular}{|c|c|c|c|}
\hline Gene Name & Location & VNTR Lenght & Repeats \\
\hline \hline Slc6a4 & 5'UTR & $20,23 \mathrm{bp}$ & $14-16,18,20,22$ \\
\hline Drd4 & Exon3 & $48 \mathrm{bp}$ & $2-11$ \\
\hline Slc6a3 (Dat1) & 3'UTR & $40 \mathrm{bp}$ & $3-16$ \\
\hline
\end{tabular}

\section{GABA Mediated Transmission}

Gamma Amino butyric acid (GABA) is the principal inhibitory neurotransmitter in the human CNS. Three different GABA receptors, called GABA-A, B and $\mathrm{C}$ are dissimilar in 
terms of molecular structure, pharmacology and signal transduction mechanism. GABA-A and GABA-C receptors (ionotropic) are ion channels regulating $\mathrm{Cl}^{-}$influx, while GABA-B receptors (metabotropic) are $G$ protein coupled receptors. The GABA-A receptors are present in the human brain mostly as pentameric structures composed of three predominant subunits $(\alpha, \beta$ and $\gamma$ ) even though different forms of GABA-A receptors (e.g. multimers of a single subunit) and adjunctive subunits have been described. In the adult human brain GABA-A receptors exist mainly as $\alpha 1 \beta 2 \gamma 2$ (60\%), $\alpha 2 \beta 3 \gamma 2$ (15\%) and $\alpha 3 \beta 3 \gamma 2$ (10\%) [52]. Clusters of genes coding for many of the different GABA-A receptor subunits are located in chromosome 4p12-p13 (Gabra2, Gabra4, Gabrb1 and Gabrgl genes coding respectively for the $\alpha 2, \alpha 4, \beta 1$ and $\gamma 1$ subunits), as well as in chromosome 5q31-q35 ( $\alpha 1, \alpha 6, \beta 2, \gamma 2)$, in chromosome $15 q 11-q 13(\alpha 5, \beta 3, \gamma 3)$ and in chromosome Xq28 $(\alpha 3, \beta 4$, ع1) $[53,54]$.

The link between GABA receptor SNPs and alcohol dependence has been previously described by several papers. Single nucleotide polymorphisms and overlapping haplotypes have emerged as feasible risk loci from different studies concerning Gabra2 and AD subjects from COGA (Collaborative Study on Genetics of Alcoholism) samples and other independent samplings [54-61], so that for AD in individuals with European and native American ancestry this gene is considered an established risk locus [62,63]. The region around exon 5 of Gabra 2 gene contains the most replicated haplotypes associated with AD: four SNPs (rs279826- rs279836- rs279871- rs279858) seem to be common in haplotypes related to $\mathrm{AD}$ alone [55] and to $\mathrm{AD}$ in comorbidity with cocaine and marijuana dependence [56]. In exon 5 , rs279858 cause a synonymous change at amino acid number 132 in the polypeptide chain causing a differential allele-related mRNA expression as assessed in brain tissue from deceased alcoholic individuals [64]. The other variations composing these haplotypes could rather be involved in gene regulation through post-transcriptional mechanisms. Other studies have been extended to the adjacent Gabrag1 gene but with a weaker correlation to AD if compared with the Gabra2 gene.

\section{Opioidergic Transmission}

The Opioid endogenous system undertakes a conspicuous number of physiological and neurological functions and also seems to perform an important role in the development and maintenance of alcohol addiction. Studies in human and animal models have shown that alcohol administration increases synthesis of opioid peptides and opiate mediated neurotransmission, stimulating an increment in alcohol consumption while opioid antagonists reverse this effect [65]. Opioidergic agents are supposed to modulate dopaminergic transmission at the mesolimbic pathway and to regulate dopamine release in the Nucleus Accumbens. In the early 1970s several groups, driven by the discovery of the strong pharmacological effect led by morphine and its specificity to induce neurobiological effect, identified the presence of opioid receptors in brain and peripheral tissues. Consequently, there was a contemporary interest in finding endogenous ligand for these receptors. In 1975 Bradbury and coworkers discovered the $\beta$-endorphin, derived from the precursor proopiomelanocortin [66]. $\beta$-endorphin as well as other opioidergic substances can activate different classes of opioid receptors $(\mu, \delta$ and $\kappa)$ eliciting morphine like effects. The $\mu$-opioid receptor is the main site of action of morphine and of the most commonly used opioids. The $\mu$ opioid receptor, encoded by the Oprml gene, shares a high grade of homology with the other opioid receptors [67]. By sequencing DNA from subjects with psychiatric disturbances related to the opioid function, Bergen and colleagues identified four sequence variations, three in the coding region of the Opmrl gene and one intronic [68]. The most relevant was an $A$ to $G$ substitution at position $118($ c. $118 \mathrm{~A}>\mathrm{G})$, which codes for the p.Asn40Asp substitution (rs1799971). This sequence variation appeared to be functional and linked to a gain of function associated to the minor allele [69]. To the contrary, a successive work considering this SNP described a loss of function rather than a gain, where the $G$ allele produced a lowering in protein expression and function [70]. Ramchandani and colleagues, in a more recent study, described, in social drinkers examined for striatal dopamine release using positron emission tomography and [11C]-raclopride displacement, a striatal dopamine increase after alcohol administration limited to subjects with the minor $G$ allele. In the same study two lines of humanized mouse carrying the human Oprml c. $118 \mathrm{~A}>\mathrm{G}$ A/A or G/G variants were created and brain microdialysis of the mouse with the Oprml G/G variant showed a fourfold greater peak of dopamine response to an alcohol challenge compared to those carrying the A/A variant [71]. Several studies tried to establish a relationship between c.118A>G Oprm1 polymorphism and alcohol and misuse of other substances (opiates mainly) with positive [72-74] or negative $[68,75-79]$ results in terms of association.

\section{Glutamatergic Transmission}

Glutamate is the major excitatory neurotransmitter in the brain and glutamatergic neurons are prominent in the cerebral cortex. Alcohol affects glutamate transmission most likely by altering the functions of ionotropic glutamate receptors (iGluRs) and of metabotropic glutamate receptors, in particular subtype 5 receptors (mGluR5) [80]. The $\mathrm{N}$ Methyl-D-aspartate (NMDA) receptors, the AMPA $(\alpha-$ Amino-3-hydroxy-5-methyl-4-isoxazolepropionic acid) receptors and the Kainate receptors represent the three main classes of the iGluRs. Ethanol has, in general, an important inhibitory effect on iGluRs and the inhibition of NMDARs, that occur at intoxicating levels of ethanol, is widely described in literature [81-84]. NMDARs are made of a mandatory NR1 subunit together with at least one NR2 or NR3 subunit. All NMDAR subtypes are inhibited by ethanol but receptors with different composition in subunits show differences in the sensitivity to inhibition. In particular, the inhibitory action of ethanol is enhanced by the presence of the NR2B-subunit in NR3-containing receptors [85]. Moreover, a large effect of EtOH on NR2B containing NMDARs was already seen in different neuronal preparations [86,87]. However, a genetic study that analyzed sequence variations in glutamatergic neurotransmission genes showed that $\mathrm{Nr} 2 \mathrm{a}$ (also known as Grin2a) and Mglur5 were the most powerful predictors of human alcohol dependence among the genes selected, even though, a subsequent replication analysis study confirmed the association of alcohol dependence only 
for $N r 2 a$ (odds ratio, 2.01) [88]. The $N r 2 a$ variations involved were a C-to-A substitution in rs2072450 (intron 11) and a deletion/insertion in rs9924016 (intron 7) and the risk genotypes were rs2072450 C/C and rs9924016 Del/Del. A more recent gene-set analysis approach performed by Karpyak and colleagues [89] using SNP data from the Study of Addiction: Genetic and Environment (SAGE) [90], showed an association between alcohol dependence and variation in the NMDA-dependent AMPA receptor trafficking cascade. Part of this molecular pathway is the calcium/calmodulin-dependent protein kinase II (CaMKII), this protein plays a key role in memory formation and recently has been increasingly involved in the development of drug addiction. In a recent work autophosphorylation deficient $\alpha \mathrm{CaMKII}$ (T286A) mice showed an accelerated conditioned place preference (CPP) compared to wild type (WT) mice suggesting a difference between the two groups in the negative reinforcing properties of alcohol [91]. Unexpected molecular targets concerning glutamatergic system function derived from a genome-wide association study meta-analysis performed by Schumann et al. [92]. The authors selected few polymorphisms that reached genome-wide significance from about 2.5 million directly genotyped or imputed SNPs with alcohol consumption in 26,316 individuals of European ancestry. Of the seven SNPs tested, only rs6943555 in autism susceptibility candidate 2 gene (Auts2) was associated with alcohol consumption at genome-wide significance. From the above mentioned study a variation in the ras-specific guanine-nucleotide releasing factor 2 (Rasgrf2) gene was further investigated by Stacey and co-workers [93]. It is well known that NMDA receptors and Ras-ERK signaling have a consistent role in alcohol-induced plasticity. Rasgrf2, a gene related to glutamatergic transmission, links NMDA receptors to the activation of the Ras-ERK signaling cascade. Pharmacological and genetic approaches, used to investigate the role of the Ras-ERK pathway and downstream gene expression in the striatum, lead to the hypotesis that an abnormal hyperactivation of Ras-ERK, which conduces to an hyperglutamatergic state, seems to be a key pathogenic factor for addictive behaviour [94,95].

\section{Acetylcholine Mediated Transmission}

Early researches on how ethanol affects cholinergic transmission are based on the observation that alcohol drinking is often associated with cigarette smoking. A recent work by Vink and collaborators support this idea revealing many common variants, with a very small individual effect size, influencing smoking behavior, alcohol and cannabis use [96]. Acetylcholine, synthesized from choline by the enzyme AcetylCoA cholineacetyltransferase (ChAT) (Ach), was the very first neurotransmitter to be identified back in the early 1900s and its distribution in the CNS was found to be similar to that of the neurotransmitter GABA. The Ach receptors system is made of two main components: the muscarinic and the nicotinic receptors. Muscarinic receptors are $\mathrm{G}$ protein coupled receptors while nicotinic receptors are ligand-gated ion channels.

Five subtypes of muscarinic receptors exist, from $\mathrm{M}_{1}$ to $\mathrm{M}_{5}$, coded by just as many genes. At least 17 different subunits $(\alpha 1-\alpha 10 ; \beta 1-\beta 4 ; \delta ; \gamma ; \varepsilon)$ are differently arranged to compose the pentameric structure of brain and muscle nico- tinic receptors. Brain nicotinic receptors are formed by an arrangement of $\alpha$ and $\beta$ subunits only. Genes for the $\alpha$ subunits are named from Chrnal to Chrnalo and for the $\beta$ subunits from Chrnbl to Chrnb4. Chrnal and Chrnbl genes code for muscle-type $\alpha 1$ and $\beta 1$ subunits respectively.

Past linkage studies showed a relationship between cholinergic muscarinic receptor-2 (Chrm2), located on the long arm of chromosome 7, and alcohol dependence [97,98]. More recently, polymorphisms of the Chrm 2 gene have been associated with alcohol dependence and major depressive syndrome [99]. Wang and colleagues using COGA samples have found several SNPs associated with alcohol dependence in the Chrm2 gene, in particular, three SNPs with a strong association: rs1824024 in intron4, rs324640 and rs324650 in intron 5. The authors also performed a haplotype analysis finding three SNPs (rs1824024-rs2061174-rs324650) that form three common haplotypes: T-T-T, G-C-A and T-T-A that represent $80 \%$ of the observed haplotypes. The common T-T-T haplotype $(>43 \%)$ is under-transmitted to alcohol dependent individuals while the rare G-T-A haplotype, is instead over-transmitted. These findings were confirmed also by other researchers [100]. A recent work by Jung and colleagues [101] describes results from a moderate sized sample of Korean control and AD subjects examining the association of Chrm 2 polymorphisms and alcohol dependence. They found a marginal association of SNP rs324650 with the risk of alcohol dependence but a significant association of SNP rs1824024 with the AUDIT (Alcohol Use Disorders Identification Test) and ADS (Alcohol Dependence Scale) scores.

Sequence variations in nicotinic acetylcholine receptor subunit genes seem to be associated with alcohol and other substance dependence. Sherva and colleagues reported two SNPs associated with alcohol dependence: rs615470 in Chrna5 and rs578776 in Chrna3 [102].

\section{GENOME-WIDE ASSOCIATION STUDIES (GWAS)}

Alcohol dependence is a complex disorder and the contribution of single genes and variations to the clinical phenotypes of addictive behavior is very hard to estimate. Recent advances in genotyping tools and the completion of the HapMap project are allowing a comprehensive genome mapping of SNPs and the possibility of hypothesis-free identification of genes that contribute to the risk of polygenic diseases. Genome wide analysis of variants concurring to increased vulnerability for alcohol addiction are constantly returning new and unpredictable targets. In the last few years a growing number of case-control GWAS studies on alcohol addiction have been published and a recent and accurate review of GWAS literature and a meta-analysis of studies meeting defined criteria was performed by Zuo and colleagues [103]. Since the development of AD has been considered to be related to alcohol metabolizing enzymes, Adh and Aldh are considered as candidate genes. Similarly AD has been reputed a brain disease and genes related to neurotransmitters are as well considered as strong candidates. All of these hypotheses helped in finding many risk genes for alcohol dependence, as reviewed above. The GWASs, overcoming the necessity of an a priori hypothesis, besides confirming the $\mathrm{ADH}$ cluster as the most robust risk locus, gave back many different targets. Serinc2, Kiaa0040, Nrd1 and $\mathrm{Htr} 7$ emerged as important risk loci related to the develop- 
ment of AD. Pknox2, Mreg, Pecr, Gpd1l, Cmtm8, Map3k9, $P c n x$, and Opa3 seem to be, to a lesser extent, involved in risk for this disease. Analysis approaches typically used by genome wide studies consider the effect of every single SNP individually. In the presence of a large effect size, when a sequence variation heavily affects protein function, it is quite easy to detect an association with the disease and its pathogenetic processes. However, when multiple sequence variations contribute to the phenotype each with a small effect, as happens for alcoholism and other multifactorial disease, it is not suitable to assess the effect of every single variation individually. The analysis strategy applied in some GWAS $[90,104,105]$, that returned no genome-wide significant association findings, denote a limited power to identify SNPs associated to AD. This reduced detection power can be attributed to the need for even larger sample sizes and more powerful statistical methods to identify the complex interactions between multiple genetic variations that contribute to the risk of complex diseases like alcoholism. Preliminary hypothesis about the power of the alleles and their frequency in the population are requested to deal with the complex calculation of the sample size for a GWAS [106]. Usually the most significant SNPs emerging from a GWAS are to be retested in an independent sample, and while it has been initially proposed that a $p$ value of $10^{-5}$ was enough to survive retesting, it is now commonly believed that at least a $p$ value of $10^{-8}$ is required. Furthermore, sample sizes required to have $90 \%$ power to repeat the findings of a previous GWAS at a $p$ value threshold of $10^{-8}$ have been calculated, with the strongest association that needs at least 2500 cases and controls to be confirmed, as assessed by Altshuler and Daly [107]. Technologies utilized in GWAS can simultaneously deal with a large number of variations but are not able to measure every known SNP. Genotyped SNPs, acting as tagging SNPs, because of linkage disequilibrium, should then predict the majority of the rest of the SNPs. A SNP that confers a small increased relative risk of disease, small enough and not be removed by selection pressure, should be seen at a higher rate in probands affected by the disease. High-risk alleles, each individually rare, "recently" arisen at random adjacent to a SNP that is not a disease allele, are not detected in a GWAS. The SNP genotype, not being related to the disease, leaves the frequency of the tagging SNP alleles the same in cases and controls. Therefore, it seems quite clear that only common, disease-associated, variants should be detected by GWAS. The theory known as common diseaselcommon variant (CDCV) [108] supports the idea that genetic variants with an appreciable frequency in the general population but a limited risk ratio (of approximately 1.2-2) are the major contributors to genetic susceptibility to common diseases. On the other hand, the common diseaselrare variant (CDRV) [108] hypothesis shifts the responsibility towards multiple rare DNA sequence variations, each with relatively high penetrance, as the major contributors to genetic susceptibility to common diseases. Each of these hypotheses is taken into consideration in current studies.

\section{PERSONALIZED MOLECULAR TREATMENT OF ALCHOL USE DISORDERS}

In Table 6 a list of the sequence variations, involved in pharmacogenetics of $\mathrm{AD}$, is produced.

\section{Pharmacological Molecules Acting on Serotoninergic Transmission}

As previously mentioned, the 5HTTLPR polymorphism has been studied indepth in relation to susceptibility to alcohol abuse and dependence, but it can work in a synergistic way with other sequence variations modulating the response to pharmacological treatments that target the serotoninergic system. Alcoholic subjects with 5-HTTLPR L/L and rs1042173 T/T genotype have a great response to therapy with ondansetron, a serotonin 5-HT3 receptor antagonist, in terms of fewer mean drinks per drinking day and a higher percentage of days abstinent compared to all the other genotypes [34]. Furthermore, in a recent paper, a panel of five markers has been introduced, combining the variations previously reported in Slc6a4 (5HTTLPR and rs1042173) with polymorphisms in the Htr3a (rs1150226 and rs1176713) and Htr3b (rs17614942) genes, that can be used to give a better prediction for the outcome of therapy with Ondansetron in AD subjects [109]. The tri-allelic polymorphism (5HTTLPR and rs25531 A to G polymorphism) can also be used to drive pharmacological therapy. Late onset alcoholics homozygotes for the $\mathrm{L}_{\mathrm{A}}$ allele, take advantages using the SSRI sertraline that reduces, only in these subjects, heavy drinking and drinking days per week, the positive effects of sertraline persisting for three months after pharmacologic treatment [110,111].

\section{Agents Acting on Dopaminergic System}

The long allele (seven repeats or more) of Drd4 VNTR polymorphism seems to have a moderating effect on the pharmacologic response to $\mu$ opioid receptor antagonist Naltrexone as shown in the study by Tidey and colleagues [112]: heavy drinkers with $\mathrm{Drd} 4 \mathrm{~L} / \mathrm{L}$ genotype reduced the percentage of heavy drinking days when treated with Naltrexone $(50 \mathrm{mg})$ and this result was found to be independent from the genotype of the Oprml gene c.118A>G (rs1799971) polymorphism. The Drd4 VNTR polymorphism was also found to regulate the efficacy of Olanzapine, a D2/5HT2 receptor blocker [113]. In a clinical trial in which 5 $\mathrm{mg}$ of Olanzapine were administered to AD subjects, craving was reduced in those carrying the $\mathrm{Drd} 4 \mathrm{~L} / \mathrm{L}$ genotype, moreover, a reduction in the number of drinks per drinking days and a reduced number of drinks in general was also observed.

\section{Naltrexone and Opioidergic Transmission}

The Oprm1 gene Asn40Asp polymorphism has an important role in the pharmacological treatment of AD. The opioid receptor antagonist Naltrexone (with a prevalent action on $\mu$ and $\kappa$ receptors) is commonly used in the therapy of alcoholism although with moderate effects. The pharmacogenetics of Naltrexone identifies individuals with a better response to this medication on the basis of their genetic background [114]. The response to Naltrexone, in AD subjects in clinical trials $[115,116]$ was found to be conditioned by the c.118A>G Oprm1 polymorphism. The presence of at least an Asp40 (G) allele has been associated with a lower relapse rate and a slower return to heavy drinking. These results have been consolidated in a larger sample from the Combining Medications and Behavioral Interventions for Alcohol- 
Table 6. Sequence variations with a pharmacogenetic effect on pharmacological treatments for AD.

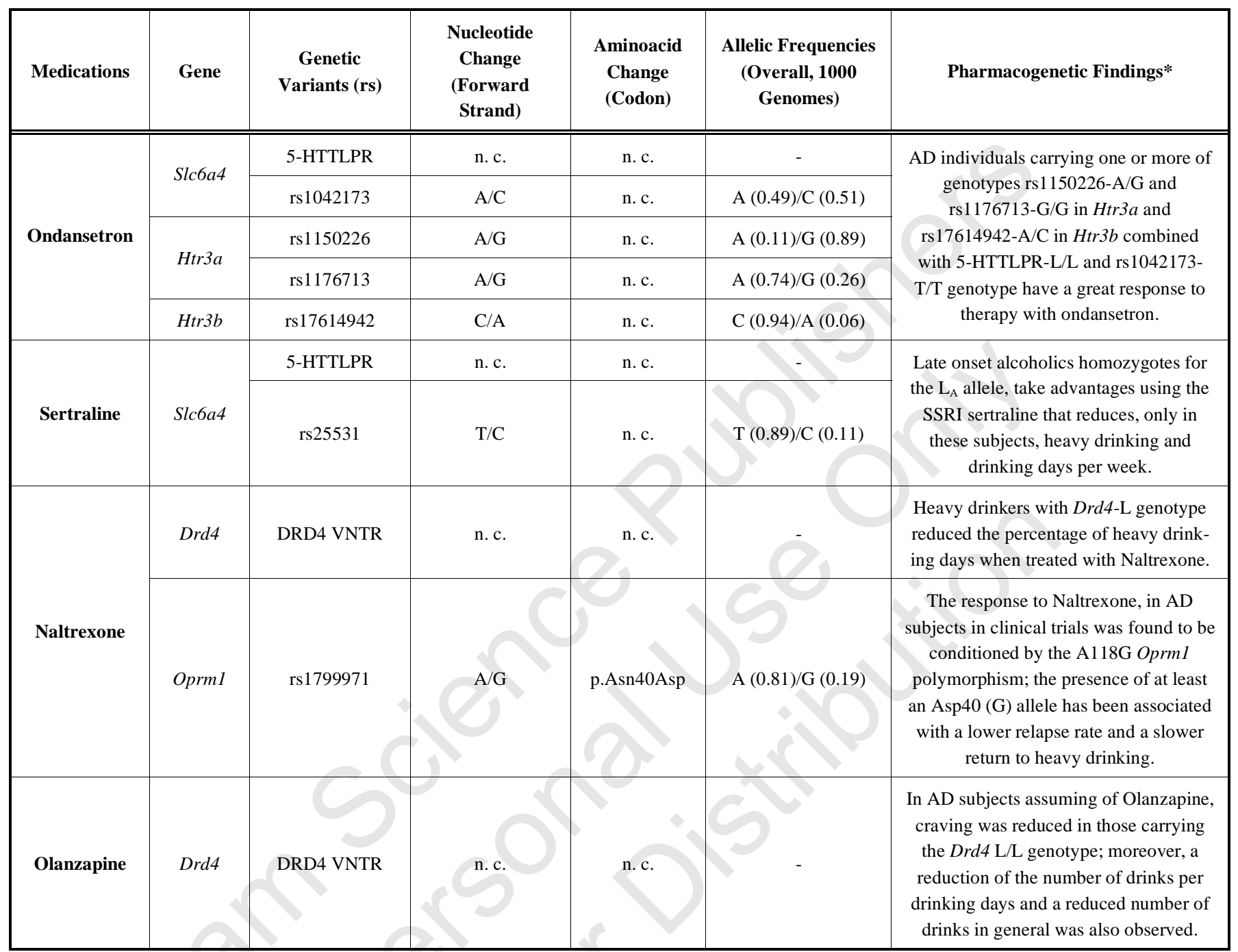

*See text for references; n. c. $=$ no change

ism (COMBINE) study [116], although the work by Gelernter et al. has failed to find this modulating role of the polymorphism [117]. Ray and colleagues [118] have presented another feature of the interaction between genotype and opiate antagonist naltrexone: the presence of the Asp40 allele contributes to trigger a biobehavioral mechanism that reduces the subjective reaction to alcohol through the dampening of the alcohol "high" and produces the clinical pharmacogenetic effect. Recently a systematic review and meta analysis of six prospective studies has confirmed the lower relapse rate, previously observed, in AD patients carrying at least a $\mathrm{G}$ allele and treated with Naltrexone [119].

\section{CONCLUSION, OPEN ISSUES AND FUTURE PROS- PECTS}

The findings reported in this review constitute a summary of the state-of-the-art of the molecular basis of AD. They constitute the best fundamental knowledge at moment available for a molecular biology-based diagnostic and therapeutic approaches of AD. However, although current research on the genetics of $\mathrm{AD}$ have shed lights on many interesting molecular targets, in terms of risk genes and molecular markers for pharmacological therapy, still more needs to be done to deeply understand the genetics of alcohol use disorders. This also depends on the fact that not all alcoholics share an identical background: different social and environmental circumstances act on different and multiple genetic substrates. Maybe this challenge should be faced in a different and possibly omni-comprehensive way. Case control studies often take into consideration only a limited number of polymorphic sites at the same time that are known (or supposed) to modulate the efficiency of certain pathways, but multiple variations, occurring in the same or in other genes, can modulate the effect of the single or the few polymorphisms evaluated. The small effect of a single variation should be counterbalanced by other polymorphisms simultaneously present and this is true e.g. for the serotonin transporter where a consistent number of polymorphic sites, with opposite effects on expression or protein function, are described and characterized. Moreover, the serotonin transporter is only one of the key points of serotonin transmission. The serotoninergic neuron possesses many other phar- 
macological targets that represent as many points of control of 5-HT transmission and each point can be affected, at a genetic level, by polymorphic regions that might regulate the efficiency of every single passage. These "check points" may be the captation of tryptophan, the hydroxylation of Ltryptophan in 5-hydroxy-tryptophan and so on up to the postsynaptic receptors and their signal transmission pathways when present. Every one of these passages can be modulated by DNA sequence variations. Furthermore, the risk of assessing a possible association in the wrong way can occur for other important reasons. A proper classification of cases and an accurate selection of controls should be done, in particular for alcohol dependent patients where, at least in half of the individuals, psychiatric comorbidities exist and often also a multi-drug dependence. The allelic frequencies of single nucleotide polymorphisms are variable among different populations and this should also be considered. The differences between the target and the control population could be, in this way, minimized, leading to an erroneous evaluation that could also be one of the reasons for the contrasting literature that is often found in association studies. In the light of these facts it is very difficult to elaborate theories based on a single or a small group of polymorphisms analyzed. In the GWAS strategy the power to detect associations can be different from gene to gene because of the non homogeneous coverage of genes by SNPs on GWAS arrays. The specific human population being studied and the SNPs selected for the assay by each platform require careful consideration. As an example, african genomes have had more time to recombine than Europeans, so they have less linkage disequilibrium between alleles at different SNPs and therefore it is important to use a chip that has more SNPs with better overall genomic coverage to study Africans. Other limitations are that chip-based microarray technology for assaying a million or more SNPs usually do not include other types of variations such as variable number of tandem repeat polymorphisms or copy number variations. One possible alternative approach is to use an entire gene set as a single entity to test for association with the phenotype of interest. Limitations of this kind of studies include, as happens for candidate gene studies, the reliance on a priori hypothesis as well as the knowledge of relevant biological pathways associated with the phenotypes of interest. Chip-based genotyping platforms will probably be replaced over the next few years with next generation sequencing (NGS) based techniques that are slowly reaching cost effectiveness. Exome sequencing, RNA sequencing and bisulfite DNA sequencing as well as whole genome sequencing NGS based, will soon provide concrete answers about the role of point mutations as well as other variants in alcohol dependence. Comparing whole genomes from a control and a target population will help to shed light not only on molecular mechanisms already known, but also to discover new and maybe unexpected molecular targets. Furthermore, the role of epigenetic processes in brain gene expression after chronic alcohol exposure is a growing and attractive field of study. Changes in methylation of DNA and histones, microRNA driven gene expression, acetylation and de-acetylation of histone proteins are associated to brain plasticity and to the development of pathologic processes involved in alcohol abuse and addiction. In the immediate future, epigenetics will probably represent the most rapid growing field within molecular mechanisms of acohol addiction.

\section{CONFLICT OF INTEREST}

The authors confirm that this article content has no conflict of interest.

\section{ACKNOWLEDGEMENTS}

Declared none.

\section{REFERENCES}

[1] American Psychiatric Association Diagnostic and Statistical Manual of Mental Disorders: DSM5 ; American Psychiatric Publishing: 2013.

[2] Gelernter, J. Genetic Factors in Alcoholism: Evidence and Implications. In The Pharmacology of Alcohol Abuse, 114 ed.; Springer: 1995; pp 297-313.

[3] Cook, C. H.; Gurling, H. D. Genetic predisposition to alcohol dependence and problems. In International Handbook of Alcohol Problems and Dependence., John Wiley\& Sons, L., Ed.; 2001.

[4] Dick, D. M.; Foroud, T. Genetic strategies to detect genes involved in alcoholism and alcohol-related traits. Alcohol Res. Health, 2002, 26(3), 172-180.

[5] Druesne-Pecollo, N.; Tehard, B.; Mallet, Y.; Gerber, M.; Norat, T.; Hercberg, S.; Latino-Martel, P. Alcohol and genetic polymorphisms: effect on risk of alcohol-related cancer. Lancet Oncol., 2009, 10(2), 173-180.

[6] Han, H.; Wang, H.; Yin, Z.; Jiang, H.; Fang, M.; Han, J. Association of genetic polymorphisms in ADH and ALDH2 with risk of coronary artery disease and myocardial infarction: a metaanalysis. Gene, 2013, 526(2), 134-141.

[7] Frank, J.; Cichon, S.; Treutlein, J.; Ridinger, M.; Mattheisen, M.; Hoffmann, P.; Herms, S.; Wodarz, N.; Soyka, M.; Zill, P.; Maier W.; Mossner, R.; Gaebel, W.; Dahmen, N.; Scherbaum, N.; Schmal, C.; Steffens, M.; Lucae, S.; Ising, M.; Muller-Myhsok, B.; Nothen, M. M.; Mann, K.; Kiefer, F.; Rietschel, M. Genome-wide significant association between alcohol dependence and a variant in the ADH gene cluster. Addict. Biol., 2012, 17(1), 171-180.

[8] Duester, G.; Farres, J.; Felder, M. R.; Holmes, R. S.; Hoog, J. O.; Pares, X.; Plapp, B. V.; Yin, S. J.; Jornvall, H. Recommended nomenclature for the vertebrate alcohol dehydrogenase gene family. Biochem. Pharmacol., 1999, 58(3), 389-395.

[9] Plapp, B. V.; Leidal, K. G.; Smith, R. K.; Murch, B. P. Kinetics of inhibition of ethanol metabolism in rats and the rate-limiting role of alcohol dehydrogenase. Arch. Biochem. Biophys., 1984, 230(1), 3038.

[10] Ji, Y. B.; Tae, K.; Ahn, T. H.; Lee, S. H.; Kim, K. R.; Park, C. W.; Park, B. L.; Shin, H. D. ADH1B and ALDH2 polymorphisms and their associations with increased risk of squamous cell carcinoma of the head and neck in the Korean population. Oral Oncol., 2011, 47(7), 583-587.

[11] Gelernter, J.; Kranzler, H. R.; Sherva, R.; Almasy, L.; Koesterer R.; Smith, A. H.; Anton, R.; Preuss, U. W.; Ridinger, M.; Rujescu, D.; Wodarz, N.; Zill, P.; Zhao, H.; Farrer, L. A. Genome-wide association study of alcohol dependence:significant findings in African- and European-Americans including novel risk loci. Mol. Psychiatry, 2014, 19(1), 41-49.

[12] Kim, D. J.; Choi, I. G.; Park, B. L.; Lee, B. C.; Ham, B. J.; Yoon, S.; Bae, J. S.; Cheong, H. S.; Shin, H. D. Major genetic components underlying alcoholism in Korean population. Hum. Mol. Genet., 2008, 17(6), 854-858.

[13] Park, B. L.; Kim, J. W.; Cheong, H. S.; Kim, L. H.; Lee, B. C.; Seo, C. H.; Kang, T. C.; Nam, Y. W.; Kim, G. B.; Shin, H. D.; Choi, I. G. Extended genetic effects of ADH cluster genes on the risk of alcohol dependence: from GWAS to replication. Hum. Genet., 2013, 132(6), 657-668.

[14] Osier, M. V.; Pakstis, A. J.; Soodyall, H.; Comas, D.; Goldman, D.; Odunsi, A.; Okonofua, F.; Parnas, J.; Schulz, L. O.; Bertranpetit, J.; Bonne-Tamir, B.; Lu, R. B.; Kidd, J. R.; Kidd, K. K. A global perspective on genetic variation at the $\mathrm{ADH}$ genes reveals unusual 
patterns of linkage disequilibrium and diversity. Am. J. Hum. Genet., 2002, 71(1), 84-99.

[15] Edenberg, H. J.; Xuei, X.; Chen, H. J.; Tian, H.; Wetherill, L. F.; Dick, D. M.; Almasy, L.; Bierut, L.; Bucholz, K. K.; Goate, A.; Hesselbrock, V.; Kuperman, S.; Nurnberger, J.; Porjesz, B.; Rice, J.; Schuckit, M.; Tischfield, J.; Begleiter, H.; Foroud, T. Association of alcohol dehydrogenase genes with alcohol dependence: a comprehensive analysis. Hum. Mol. Genet., 2006, 15(9), 1539-1549.

[16] Luo, X.; Kranzler, H. R.; Zuo, L.; Wang, S.; Schork, N. J.; Gelernter, J. Diplotype trend regression analysis of the ADH gene cluster and the ALDH2 gene: multiple significant associations with alcohol dependence. Am. J. Hum. Genet., 2006, 78(6), 973-987.

[17] Wall, T. L.; Carr, L. G.; Ehlers, C. L. Protective association of genetic variation in alcohol dehydrogenase with alcohol dependence in Native American Mission Indians. Am. $J$. Psychiatry, 2003, $160(1), 41-46$.

[18] McCarthy, D. M.; Pedersen, S. L.; Lobos, E. A.; Todd, R. D.; Wall, T. L. ADH1B*3 and response to alcohol in African-Americans. Alcohol Clin. Exp. Res., 2010, 34(7), 1274-1281.

[19] Higuchi, S.; Matsushita, S.; Muramatsu, T.; Murayama, M.; Hayashida, M. Alcohol and aldehyde dehydrogenase genotypes and drinking behavior in Japanese. Alcohol Clin. Exp. Res., 1996, 20(3), 493-497.

[20] Shen, Y. C.; Fan, J. H.; Edenberg, H. J.; Li, T. K.; Cui, Y. H.; Wang, Y. F.; Tian, C. H.; Zhou, C. F.; Zhou, R. L.; Wang, J.; Zhao, Z. L.; Xia, G. Y. Polymorphism of ADH and ALDH genes among four ethnic groups in China and effects upon the risk for alcoholism. Alcohol Clin. Exp. Res., 1997, 21(7), 1272-1277.

[21] Osier, M.; Pakstis, A. J.; Kidd, J. R.; Lee, J. F.; Yin, S. J.; Ko, H. C.; Edenberg, H. J.; Lu, R. B.; Kidd, K. K. Linkage disequilibrium at the ADH2 and ADH3 loci and risk of alcoholism. Am. J. Hum. Genet., 1999, 64(4), 1147-1157.

[22] Kimura, Y.; Nishimura, F. T.; Abe, S.; Fukunaga, T.; Tanii, H.; Saijoh, K. Polymorphisms in the promoter region of the human class II alcohol dehydrogenase (ADH4) gene affect both transcriptional activity and ethanol metabolism in Japanese subjects. J. Toxicol. Sci., 2009, 34(1), 89-97.

[23] Luo, X.; Kranzler, H. R.; Zuo, L.; Lappalainen, J.; Yang, B. Z.; Gelernter, J. ADH4 gene variation is associated with alcohol dependence and drug dependence in European Americans: results from HWD tests and case-control association studies. Neuropsychopharmacology, 2006, 31(5), 1085-1095.

[24] Preuss, U. W.; Ridinger, M.; Rujescu, D.; Samochowiec, J.; Fehr, C.; Wurst, F. M.; Koller, G.; Bondy, B.; Wodarz, N.; Debniak, T.; Grzywacz, A.; Soyka, M.; Zill, P. Association of ADH4 genetic variants with alcohol dependence risk and related phenotypes: results from a larger multicenter association study. Addict. Biol., 2011, 16(2), 323-333.

[25] Liu, J.; Zhou, Z.; Hodgkinson, C. A.; Yuan, Q.; Shen, P. H.; Mulligan, C. J.; Wang, A.; Gray, R. R.; Roy, A.; Virkkunen, M.; Goldman, D.; Enoch, M. A. Haplotype-based study of the association of alcohol-metabolizing genes with alcohol dependence in four independent populations. Alcohol Clin. Exp. Res., 2011, 35(2), 304-316.

[26] Gingrich, J. A.; Hen, R. Dissecting the role of the serotonin system in neuropsychiatric disorders using knockout mice. Psychopharmacology (Berl.), 2001, 155(1), 1-10.

[27] Murphy, D. L.; Lerner, A.; Rudnick, G.; Lesch, K. P. Serotonin transporter: gene, genetic disorders, and pharmacogenetics. Mol. Interv., 2004, 4(2), 109-123.

[28] Heinz, A.; Mann, K.; Weinberger, D. R.; Goldman, D. Serotonergic dysfunction, negative mood states, and response to alcohol. Alcohol Clin. Exp. Res., 2001, 25(4), 487-495.

[29] Muller, C. P.; Homberg, J. R. The role of serotonin in drug use and addiction. Behav. Brain Res., 2015, 277C, 146-192.

[30] Johnson, B. A. Serotonergic agents and alcoholism treatment: rebirth of the subtype concept--an hypothesis. Alcohol Clin. Exp. Res., 2000, 24(10), 1597-1601.

[31] Lesch, K. P.; Balling, U.; Gross, J.; Strauss, K.; Wolozin, B. L.; Murphy, D. L.; Riederer, P. Organization of the human serotonin transporter gene. J. Neural Transm. Gen. Sect., 1994, 95(2), 157162.

[32] Ramamoorthy, S.; Bauman, A. L.; Moore, K. R.; Han, H.; YangFeng, T.; Chang, A. S.; Ganapathy, V.; Blakely, R. D. Antidepressant- and cocaine-sensitive human serotonin transporter: molecular cloning, expression, and chromosomal localization. Proc. Natl. Acad. Sci. U. S. A, 1993, 90(6), 2542-2546.

[33] McHugh, R. K.; Hofmann, S. G.; Asnaani, A.; Sawyer, A. T.; Otto, M. W. The serotonin transporter gene and risk for alcohol dependence: a meta-analytic review. Drug Alcohol Depend., 2010, 108(1-2), 1-6.

[34] Johnson, B. A.; Ait-Daoud, N.; Seneviratne, C.; Roache, J. D. Javors, M. A.; Wang, X. Q.; Liu, L.; Penberthy, J. K.; DiClemente, C. C.; Li, M. D. Pharmacogenetic approach at the serotonin transporter gene as a method of reducing the severity of alcohol drinking. Am. J. Psychiatry, 2011, 168(3), 265-275.

[35] Seneviratne, C.; Huang, W.; Ait-Daoud, N.; Li, M. D.; Johnson, B. A. Characterization of a functional polymorphism in the 3' UTR of SLC6A4 and its association with drinking intensity. Alcohol Clin. Exp. Res., 2009, 33(2), 332-339.

[36] Hu, X. Z.; Lipsky, R. H.; Zhu, G.; Akhtar, L. A.; Taubman, J.; Greenberg, B. D.; Xu, K.; Arnold, P. D.; Richter, M. A.; Kennedy, J. L.; Murphy, D. L.; Goldman, D. Serotonin transporter promoter gain-of-function genotypes are linked to obsessive-compulsive disorder. Am. J. Hum. Genet., 2006, 78(5), 815-826.

[37] Seneviratne, C.; Franklin, J.; Beckett, K.; Ma, J. Z.; Ait-Daoud, N.; Payne, T. J.; Johnson, B. A.; Li, M. D. Association, interaction, and replication analysis of genes encoding serotonin transporter and 5HT3 receptor subunits $\mathrm{A}$ and $\mathrm{B}$ in alcohol dependence. Hum. Genet., 2013, 132(10), 1165-1176.

[38] Weiss, F.; Lorang, M. T.; Bloom, F. E.; Koob, G. F. Oral alcohol self-administration stimulates dopamine release in the rat nucleus accumbens: genetic and motivational determinants. J. Pharmacol. Exp. Ther., 1993, 267(1), 250-258.

[39] Melendez, R. I.; Rodd-Henricks, Z. A.; Engleman, E. A.; Li, T. K.; McBride, W. J.; Murphy, J. M. Microdialysis of dopamine in the nucleus accumbens of alcohol-preferring (P) rats during anticipation and operant self-administration of ethanol. Alcohol Clin. Exp. Res., 2002, 26(3), 318-325.

[40] Brodie, M. S.; Shefner, S. A.; Dunwiddie, T. V. Ethanol increases the firing rate of dopamine neurons of the rat ventral tegmental area in vitro. Brain Res., 1990, 508(1), 65-69.

[41] Schellekens, A. F.; Franke, B.; Ellenbroek, B.; Cools, A.; de Jong, C. A.; Buitelaar, J. K.; Verkes, R. J. Reduced dopamine receptor sensitivity as an intermediate phenotype in alcohol dependence and the role of the COMT Val158Met and DRD2 Taq1A genotypes. Arch. Gen. Psychiatry, 2012, 69(4), 339-348.

[42] Neville, M. J.; Johnstone, E. C.; Walton, R. T. Identification and characterization of ANKK1: a novel kinase gene closely linked to DRD2 on chromosome band 11q23.1. Hum. Mutat., 2004, 23(6), 540-545.

[43] Smith, L.; Watson, M.; Gates, S.; Ball, D.; Foxcroft, D. Metaanalysis of the association of the Taq1A polymorphism with the risk of alcohol dependency: a HuGE gene-disease association review. Am. J. Epidemiol., 2008, 167(2), 125-138.

[44] Mignini, F.; Napolioni, V.; Codazzo, C.; Carpi, F. M.; Vitali, M.; Romeo, M.; Ceccanti, M. DRD2/ANKK1 TaqIA and SLC6A3 VNTR polymorphisms in alcohol dependence: association and gene-gene interaction study in a population of Central Italy. Neurosci. Lett., 2012, 522 (2), 103-107.

[45] Batel, P.; Houchi, H.; Daoust, M.; Ramoz, N.; Naassila, M. Gorwood, P. A haplotype of the DRD1 gene is associated with alcohol dependence. Alcohol Clin. Exp. Res., 2008, 32(4), 567-572.

[46] Giros, B.; El, M. S.; Godinot, N.; Zheng, K.; Han, H.; Yang-Feng, T.; Caron, M. G. Cloning, pharmacological characterization, and chromosome assignment of the human dopamine transporter. Mol. Pharmacol., 1992, 42(3), 383-390.

[47] Du, Y.; Nie, Y.; Li, Y.; Wan, Y. J. The association between the SLC6A3 VNTR 9-repeat allele and alcoholism-a meta-analysis. Alcohol Clin. Exp. Res., 2011, 35(9), 1625-1634.

[48] Xu, M.; Lin, Z. Genetic influences of dopamine transport gene on alcohol dependence: a pooled analysis of 13 studies with 2483 cases and 1753 controls. Prog. Neuropsychopharmacol. Biol. Psychiatry, 2011, 35(5), 1255-1260.

[49] Tiihonen, J.; Hallikainen, T.; Lachman, H.; Saito, T.; Volavka, J.; Kauhanen, J.; Salonen, J. T.; Ryynanen, O. P.; Koulu, M.; Karvonen, M. K.; Pohjalainen, T.; Syvalahti, E.; Hietala, J. Association between the functional variant of the catechol-Omethyltransferase (COMT) gene and type 1 alcoholism. Mol. Psychiatry, 1999, 4(3), 286-289. 
[50] Enoch, M. A.; Waheed, J. F.; Harris, C. R.; Albaugh, B.; Goldman, D. Sex differences in the influence of COMT Val158Met on alcoholism and smoking in plains American Indians. Alcohol Clin. Exp. Res., 2006, 30(3), 399-406.

[51] Foroud, T.; Wetherill, L. F.; Dick, D. M.; Hesselbrock, V.; Nurnberger, J. I., Jr.; Kramer, J.; Tischfield, J.; Schuckit, M.; Bierut, L. J.; Xuei, X.; Edenberg, H. J. Lack of association of alcohol dependence and habitual smoking with catechol-Omethyltransferase. Alcohol Clin. Exp. Res., 2007, 31 (11), 17731779 .

[52] Cui, W. Y.; Seneviratne, C.; Gu, J.; Li, M. D. Genetics of GABAergic signaling in nicotine and alcohol dependence. Hum. Genet., 2012, 131(6), 843-855.

[53] Darlison, M. G.; Pahal, I.; Thode, C. Consequences of the evolution of the GABA(A) receptor gene family. Cell Mol. Neurobiol., 2005, 25(3-4), 607-624.

[54] Enoch, M. A. The role of GABA(A) receptors in the development of alcoholism. Pharmacol. Biochem. Behav., 2008, 90(1), 95-104.

[55] Edenberg, H. J.; Dick, D. M.; Xuei, X.; Tian, H.; Almasy, L.; Bauer, L. O.; Crowe, R. R.; Goate, A.; Hesselbrock, V.; Jones, K.; Kwon, J.; Li, T. K.; Nurnberger, J. I., Jr.; O'Connor, S. J.; Reich, T.; Rice, J.; Schuckit, M. A.; Porjesz, B.; Foroud, T.; Begleiter, H. Variations in GABRA2, encoding the alpha 2 subunit of the GABA(A) receptor, are associated with alcohol dependence and with brain oscillations. Am. J. Hum. Genet., 2004, 74(4), 705-714.

[56] Agrawal, A.; Edenberg, H. J.; Foroud, T.; Bierut, L. J.; Dunne, G.; Hinrichs, A. L.; Nurnberger, J. I.; Crowe, R.; Kuperman, S.; Schuckit, M. A.; Begleiter, H.; Porjesz, B.; Dick, D. M. Association of GABRA2 with drug dependence in the collaborative study of the genetics of alcoholism sample. Behav. Genet., 2006, 36(5), 640-650.

[57] Dick, D. M.; Agrawal, A.; Schuckit, M. A.; Bierut, L.; Hinrichs, A.; Fox, L.; Mullaney, J.; Cloninger, C. R.; Hesselbrock, V.; Nurnberger, J. I., Jr.; Almasy, L.; Foroud, T.; Porjesz, B.; Edenberg, H.; Begleiter, H. Marital status, alcohol dependence, and GABRA2: evidence for gene-environment correlation and interaction. J. Stud. Alcohol, 2006, 67(2), 185-194.

[58] Covault, J.; Gelernter, J.; Hesselbrock, V.; Nellissery, M.; Kranzler, H. R. Allelic and haplotypic association of GABRA2 with alcohol dependence. Am. J. Med. Genet. B Neuropsychiatr. Genet., 2004, 129B(1), 104-109.

[59] Enoch, M. A.; Schwartz, L.; Albaugh, B.; Virkkunen, M.; Goldman, D. Dimensional anxiety mediates linkage of GABRA2 haplotypes with alcoholism. Am. J. Med. Genet. B Neuropsychiatr. Genet., 2006, $141 B(6), 599-607$.

[60] Fehr, C.; Sander, T.; Tadic, A.; Lenzen, K. P.; Anghelescu, I.; Klawe, C.; Dahmen, N.; Schmidt, L. G.; Szegedi, A. Confirmation of association of the GABRA2 gene with alcohol dependence by subtype-specific analysis. Psychiatr. Genet., 2006, 16(1), 9-17.

[61] Lind, P. A.; Macgregor, S.; Agrawal, A.; Montgomery, G. W.; Heath, A. C.; Martin, N. G.; Whitfield, J. B. The role of GABRA2 in alcohol dependence, smoking, and illicit drug use in an Australian population sample. Alcohol Clin. Exp. Res., 2008, 32(10), 1721-1731.

[62] Gelernter, J.; Kranzler, H. R. Genetics of alcohol dependence. Hum. Genet, 2009, 126(1), 91-99.

[63] Li, M. D.; Burmeister, M. New insights into the genetics of addiction. Nat. Rev. Genet., 2009, 10(4), 225-231.

[64] Haughey, H. M.; Ray, L. A.; Finan, P.; Villanueva, R.; Niculescu, M.; Hutchison, K. E. Human gamma-aminobutyric acid A receptor alpha2 gene moderates the acute effects of alcohol and brain mRNA expression. Genes Brain Behav., 2008, 7(4), 447-454.

[65] Ulm, R. R.; Volpicelli, J. R.; Volpicelli, L. A. Opiates and alcohol self-administration in animals. J. Clin. Psychiatry, 1995, 56 Suppl 7, 5-14.

[66] Bradbury, A. F.; Smyth, D. G.; Snell, C. R. In Peptides: chemistry, structure and biology. Ann Arbor: Ann Arbor science Inc.: 1975; pp 61-65.

[67] Kieffer, B. L. Recent advances in molecular recognition and signal transduction of active peptides: receptors for opioid peptides. Cell Mol. Neurobiol., 1995, 15(6), 615-635.

[68] Bergen, A. W.; Kokoszka, J.; Peterson, R.; Long, J. C.; Virkkunen, M.; Linnoila, M.; Goldman, D. Mu opioid receptor gene variants: lack of association with alcohol dependence. Mol. Psychiatry, 1997, 2(6), 490-494.
[69] Bond, C.; LaForge, K. S.; Tian, M.; Melia, D.; Zhang, S.; Borg, L.; Gong, J.; Schluger, J.; Strong, J. A.; Leal, S. M.; Tischfield, J. A.; Kreek, M. J.; Yu, L. Single-nucleotide polymorphism in the human mu opioid receptor gene alters beta-endorphin binding and activity: possible implications for opiate addiction. Proc. Natl. Acad. Sci. U. S. A, 1998, 95(16), 9608-9613.

[70] Zhang, Y.; Wang, D.; Johnson, A. D.; Papp, A. C.; Sadee, W. Allelic expression imbalance of human mu opioid receptor (OPRM1) caused by variant A118G. J. Biol. Chem., 2005, 280(38), 32618-32624.

[71] Ramchandani, V. A.; Umhau, J.; Pavon, F. J.; Ruiz-Velasco, V.; Margas, W.; Sun, H.; Damadzic, R.; Eskay, R.; Schoor, M.; Thorsell, A.; Schwandt, M. L.; Sommer, W. H.; George, D. T.; Parsons, L. H.; Herscovitch, P.; Hommer, D.; Heilig, M. A genetic determinant of the striatal dopamine response to alcohol in men. Mol. Psychiatry, 2011, 16(8), 809-817.

[72] Schinka, J. A.; Town, T.; Abdullah, L.; Crawford, F. C.; Ordorica, P. I.; Francis, E.; Hughes, P.; Graves, A. B.; Mortimer, J. A.; Mullan, M. A functional polymorphism within the mu-opioid receptor gene and risk for abuse of alcohol and other substances. Mol. Psychiatry, 2002, 7(2), 224-228.

[73] Kranzler, H. R.; Gelernter, J.; O'Malley, S.; Hernandez-Avila, C. A.; Kaufman, D. Association of alcohol or other drug dependence with alleles of the mu opioid receptor gene (OPRM1). Alcohol Clin. Exp. Res., 1998, 22(6), 1359-1362.

[74] Town, T.; Abdullah, L.; Crawford, F.; Schinka, J.; Ordorica, P. I.; Francis, E.; Hughes, P.; Duara, R.; Mullan, M. Association of a functional mu-opioid receptor allele $(+118 \mathrm{~A})$ with alcohol dependency. Am. J. Med. Genet., 1999, 88(5), 458-461.

[75] Arias, A.; Feinn, R.; Kranzler, H. R. Association of an Asn40Asp (A118G) polymorphism in the mu-opioid receptor gene with substance dependence: a meta-analysis. Drug Alcohol Depend., 2006, 83(3), 262-268.

[76] Gelernter, J.; Kranzler, H.; Cubells, J. Genetics of two mu opioid receptor gene (OPRM1) exon I polymorphisms: population studies, and allele frequencies in alcohol- and drug-dependent subjects. Mol. Psychiatry, 1999, 4(5), 476-483.

[77] Franke, P.; Wang, T.; Nothen, M. M.; Knapp, M.; Neidt, H.; Albrecht, S.; Jahnes, E.; Propping, P.; Maier, W. Nonreplication of association between mu-opioid-receptor gene (OPRM1) A118G polymorphism and substance dependence. Am. J. Med. Genet., 2001, 105(1), 114-119.

[78] Luo, X.; Kranzler, H. R.; Zhao, H.; Gelernter, J. Haplotypes at the OPRM1 locus are associated with susceptibility to substance dependence in European-Americans. Am. J. Med. Genet. B Neuropsychiatr. Genet., 2003, 120B(1), 97-108.

[79] Rouvinen-Lagerstrom, N.; Lahti, J.; Alho, H.; Kovanen, L.; Aalto, M.; Partonen, T.; Silander, K.; Sinclair, D.; Raikkonen, K.; Eriksson, J. G.; Palotie, A.; Koskinen, S.; Saarikoski, S. T. muOpioid Receptor Gene (OPRM1) Polymorphism A118G: Lack of Association in Finnish Populations with Alcohol Dependence or Alcohol Consumption. Alcohol Alcohol, 2013, 48(5), 519-525.

[80] Cozzoli, D. K.; Goulding, S. P.; Zhang, P. W.; Xiao, B.; Hu, J. H.; Ary, A. W.; Obara, I.; Rahn, A.; Abou-Ziab, H.; Tyrrel, B.; Marini, C.; Yoneyama, N.; Metten, P.; Snelling, C.; Dehoff, M. H.; Crabbe, J. C.; Finn, D. A.; Klugmann, M.; Worley, P. F.; Szumlinski, K. K. Binge drinking upregulates accumbens mGluR5-Homer2-PI3K signaling: functional implications for alcoholism. J. Neurosci., 2009, 29(27), 8655-8668.

[81] Criswell, H. E.; Ming, Z.; Griffith, B. L.; Breese, G. R. Comparison of effect of ethanol on N-methyl-D-aspartate- and GABA-gated currents from acutely dissociated neurons: absence of regional differences in sensitivity to ethanol. J. Pharmacol. Exp. Ther., 2003, 304(1), 192-199.

[82] Dildy, J. E.; Leslie, S. W. Ethanol inhibits NMDA-induced increases in free intracellular $\mathrm{Ca} 2+$ in dissociated brain cells. Brain Res., 1989, 499(2), 383-387.

[83] Hoffman, P. L.; Rabe, C. S.; Moses, F.; Tabakoff, B. N-methyl-Daspartate receptors and ethanol: inhibition of calcium flux and cyclic GMP production. J. Neurochem., 1989, 52(6), 1937-1940.

[84] Lovinger, D. M.; White, G.; Weight, F. F. Ethanol inhibits NMDAactivated ion current in hippocampal neurons. Science, 1989, 243(4899), 1721-1724.

[85] Jin, C.; Smothers, C. T.; Woodward, J. J. Enhanced ethanol inhibition of recombinant N-methyl-D-aspartate receptors by 
magnesium: role of NR3A subunits. Alcohol Clin. Exp. Res., 2008, 32(6), 1059-1066.

[86] Fink, K.; Gothert, M. Both ethanol and ifenprodil inhibit NMDAevoked release of various neurotransmitters at different, yet proportional potency: potential relation to NMDA receptor subunit composition. Naunyn Schmiedebergs Arch. Pharmacol., 1996, 354(3), 312-319.

[87] Lovinger, D. M. Developmental decrease in ethanol inhibition of N-methyl-D-aspartate receptors in rat neocortical neurons: relation to the actions of ifenprodil. J. Pharmacol. Exp. Ther., 1995, 274(1), 164-172.

[88] Schumann, G.; Johann, M.; Frank, J.; Preuss, U.; Dahmen, N.; Laucht, M.; Rietschel, M.; Rujescu, D.; Lourdusamy, A.; Clarke, T. K.; Krause, K.; Dyer, A.; Depner, M.; Wellek, S.; Treutlein, J.; Szegedi, A.; Giegling, I.; Cichon, S.; Blomeyer, D.; Heinz, A.; Heath, S.; Lathrop, M.; Wodarz, N.; Soyka, M.; Spanagel, R.; Mann, K. Systematic analysis of glutamatergic neurotransmission genes in alcohol dependence and adolescent risky drinking behavior. Arch. Gen. Psychiatry, 2008, 65(7), 826-838.

[89] Karpyak, V. M.; Geske, J. R.; Colby, C. L.; Mrazek, D. A.; Biernacka, J. M. Genetic variability in the NMDA-dependent AMPA trafficking cascade is associated with alcohol dependence. Addict. Biol., 2012, 17(4), 798-806.

[90] Bierut, L. J.; Agrawal, A.; Bucholz, K. K.; Doheny, K. F.; Laurie, C.; Pugh, E.; Fisher, S.; Fox, L.; Howells, W.; Bertelsen, S.; Hinrichs, A. L.; Almasy, L.; Breslau, N.; Culverhouse, R. C.; Dick, D. M.; Edenberg, H. J.; Foroud, T.; Grucza, R. A.; Hatsukami, D.; Hesselbrock, V.; Johnson, E. O.; Kramer, J.; Krueger, R. F.; Kuperman, S.; Lynskey, M.; Mann, K.; Neuman, R. J.; Nothen, M. M.; Nurnberger, J. I., Jr.; Porjesz, B.; Ridinger, M.; Saccone, N. L.; Saccone, S. F.; Schuckit, M. A.; Tischfield, J. A.; Wang, J. C.; Rietschel, M.; Goate, A. M.; Rice, J. P. A genome-wide association study of alcohol dependence. Proc. Natl. Acad. Sci. USA, 2010, 107(11), 5082-5087.

[91] Easton, A. C.; Lucchesi, W.; Mizuno, K.; Fernandes, C.; Schumann, G.; Giese, K. P.; Muller, C. P. alphaCaMKII autophosphorylation controls the establishment of alcohol-induced conditioned place preference in mice. Behav. Brain Res., 2013, 252, 72-76.

[92] Schumann, G.; Coin, L. J.; Lourdusamy, A.; Charoen, P.; Berger, K. H.; Stacey, D.; Desrivieres, S.; Aliev, F. A.; Khan, A. A.; Amin, N.; Aulchenko, Y. S.; Bakalkin, G.; Bakker, S. J.; Balkau, B.; Beulens, J. W.; Bilbao, A.; de Boer, R. A.; Beury, D.; Bots, M. L.; Breetvelt, E. J.; Cauchi, S.; Cavalcanti-Proenca, C.; Chambers, J. C.; Clarke, T. K.; Dahmen, N.; de Geus, E. J.; Dick, D.; Ducci, F.; Easton, A.; Edenberg, H. J.; Esko, T.; Fernandez-Medarde, A.; Foroud, T.; Freimer, N. B.; Girault, J. A.; Grobbee, D. E.; Guarrera, S.; Gudbjartsson, D. F.; Hartikainen, A. L.; Heath, A. C.; Hesselbrock, V.; Hofman, A.; Hottenga, J. J.; Isohanni, M. K.; Kaprio, J.; Khaw, K. T.; Kuehnel, B.; Laitinen, J.; Lobbens, S.; Luan, J.; Mangino, M.; Maroteaux, M.; Matullo, G.; McCarthy, M. I.; Mueller, C.; Navis, G.; Numans, M. E.; Nunez, A.; Nyholt, D. R.; Onland-Moret, C. N.; Oostra, B. A.; O'Reilly, P. F.; Palkovits, M.; Penninx, B. W.; Polidoro, S.; Pouta, A.; Prokopenko, I.; Ricceri, F.; Santos, E.; Smit, J. H.; Soranzo, N.; Song, K.; Sovio, U.; Stumvoll, M.; Surakk, I.; Thorgeirsson, T. E.; Thorsteinsdottir, U.; Troakes, C.; Tyrfingsson, T.; Tonjes, A.; Uiterwaal, C. S.; Uitterlinden, A. G.; van der Harst, P.; van der Schouw, Y. T.; Staehlin, O.; Vogelzangs, N.; Vollenweider, P.; Waeber, G.; Wareham, N. J.; Waterworth, D. M.; Whitfield, J. B.; Wichmann, E. H.; Willemsen, G.; Witteman, J. C.; Yuan, X.; Zhai, G.; Zhao, J. H.; Zhang, W.; Martin, N. G.; Metspalu, A.; Doering, A.; Scott, J.; Spector, T. D.; Loos, R. J.; Boomsma, D. I.; Mooser, V.; Peltonen, L.; Stefansson, K.; van Duijn, C. M.; Vineis, P.; Sommer, W. H.; Kooner, J. S.; Spanagel, R.; Heberlein, U. A.; Jarvelin, M. R.; Elliott, P. Genome-wide association and genetic functional studies identify autism susceptibility candidate 2 gene (AUTS2) in the regulation of alcohol consumption. Proc. Natl. Acad. Sci. USA, 2011, 108(17), 7119-7124.

[93] Stacey, D.; Bilbao, A.; Maroteaux, M.; Jia, T.; Easton, A. C.; Longueville, S.; Nymberg, C.; Banaschewski, T.; Barker, G. J.; Buchel, C.; Carvalho, F.; Conrod, P. J.; Desrivieres, S.; FauthBuhler, M.; Fernandez-Medarde, A.; Flor, H.; Gallinat, J.; Garavan, H.; Bokde, A. L.; Heinz, A.; Ittermann, B.; Lathrop, M.; Lawrence, C.; Loth, E.; Lourdusamy, A.; Mann, K. F.; Martinot, J. L.; Nees, F.; Palkovits, M.; Paus, T.; Pausova, Z.; Rietschel, M.; Ruggeri, B.;
Santos, E.; Smolka, M. N.; Staehlin, O.; Jarvelin, M. R.; Elliott, P.; Sommer, W. H.; Mameli, M.; Muller, C. P.; Spanagel, R.; Girault, J. A.; Schumann, G. RASGRF2 regulates alcohol-induced reinforcement by influencing mesolimbic dopamine neuron activity and dopamine release. Proc. Natl. Acad. Sci. USA, 2012, 109(51), 21128-21133.

[94] Schroeder, J. P.; Spanos, M.; Stevenson, J. R.; Besheer, J.; Salling, M.; Hodge, C. W. Cue-induced reinstatement of alcohol-seeking behavior is associated with increased ERK1/2 phosphorylation in specific limbic brain regions: blockade by the mGluR5 antagonist MPEP. Neuropharmacology, 2008, 55(4), 546-554.

[95] Fasano, S.; Brambilla, R. Ras-ERK Signaling in Behavior: Old Questions and New Perspectives. Front. Behav. Neurosci., 2011, 5, 79.

[96] Vink, J. M.; Hottenga, J. J.; de Geus, E. J.; Willemsen, G.; Neale, M. C.; Furberg, H.; Boomsma, D. I. Polygenic risk scores for smoking: predictors for alcohol and cannabis use? Addiction, 2014, 109(7), 1141-1151.

[97] Reich, T.; Edenberg, H. J.; Goate, A.; Williams, J. T.; Rice, J. P.; Van, E. P.; Foroud, T.; Hesselbrock, V.; Schuckit, M. A.; Bucholz, K.; Porjesz, B.; Li, T. K.; Conneally, P. M.; Nurnberger, J. I., Jr.; Tischfield, J. A.; Crowe, R. R.; Cloninger, C. R.; Wu, W.; Shears, S.; Carr, K.; Crose, C.; Willig, C.; Begleiter, H. Genome-wide search for genes affecting the risk for alcohol dependence. Am. J. Med. Genet., 1998, 81(3), 207-215.

[98] Foroud, T.; Edenberg, H. J.; Goate, A.; Rice, J.; Flury, L.; Koller, D. L.; Bierut, L. J.; Conneally, P. M.; Nurnberger, J. I.; Bucholz, K. K.; Li, T. K.; Hesselbrock, V.; Crowe, R.; Schuckit, M.; Porjesz, B.; Begleiter, H.; Reich, T. Alcoholism susceptibility loci confirmation studies in a replicate sample and further mapping. Alcohol Clin. Exp. Res., 2000, 24(7), 933-945.

[99] Wang, J. C.; Hinrichs, A. L.; Stock, H.; Budde, J.; Allen, R.; Bertelsen, S.; Kwon, J. M.; Wu, W.; Dick, D. M.; Rice, J.; Jones, K.; Nurnberger, J. I., Jr.; Tischfield, J.; Porjesz, B.; Edenberg, H. J.; Hesselbrock, V.; Crowe, R.; Schuckit, M.; Begleiter, H.; Reich, T.; Goate, A. M.; Bierut, L. J. Evidence of common and specific genetic effects: association of the muscarinic acetylcholine receptor M2 (CHRM2) gene with alcohol dependence and major depressive syndrome. Hum. Mol. Genet., 2004, 13(17), 1903-1911.

[100] Luo, X.; Kranzler, H. R.; Zuo, L.; Wang, S.; Blumberg, H. P.; Gelernter, J. CHRM2 gene predisposes to alcohol dependence, drug dependence and affective disorders: results from an extended case-control structured association study. Hum. Mol. Genet., 2005, 14(16), 2421-2434.

[101] Jung, M. H.; Park, B. L.; Lee, B. C.; Ro, Y.; Park, R.; Shin, H. D.; Bae, J. S.; Kang, T. C.; Choi, I. G. Association of CHRM2 polymorphisms with severity of alcohol dependence. Genes Brain Behav., 2011, 10(2), 253-256.

[102] Sherva, R.; Kranzler, H. R.; Yu, Y.; Logue, M. W.; Poling, J.; Arias, A. J.; Anton, R. F.; Oslin, D.; Farrer, L. A.; Gelernter, J. Variation in nicotinic acetylcholine receptor genes is associated with multiple substance dependence phenotypes. Neuropsychopharmacology, 2010, 35(9), 1921-1931.

[103] Zuo, L.; Lu, L.; Tan, Y.; Pan, X.; Cai, Y.; Wang, X.; Hong, J.; Zhong, C.; Wang, F.; Zhang, X. Y.; Vanderlinden, L. A.; Tabakoff, B.; Luo, X. Genome-wide association discoveries of alcohol dependence. Am. J. Addict., 2014, 23(6), 526-539.

[104] Treutlein, J.; Cichon, S.; Ridinger, M.; Wodarz, N.; Soyka, M.; Zill, P.; Maier, W.; Moessner, R.; Gaebel, W.; Dahmen, N.; Fehr, C.; Scherbaum, N.; Steffens, M.; Ludwig, K. U.; Frank, J.; Wichmann, H. E.; Schreiber, S.; Dragano, N.; Sommer, W. H.; Leonardi-Essmann, F.; Lourdusamy, A.; Gebicke-Haerter, P.; Wienker, T. F.; Sullivan, P. F.; Nothen, M. M.; Kiefer, F.; Spanagel, R.; Mann, K.; Rietschel, M. Genome-wide association study of alcohol dependence. Arch. Gen. Psychiatry, 2009, 66(7), 773-784.

[105] Edenberg, H. J.; Koller, D. L.; Xuei, X.; Wetherill, L.; McClintick, J. N.; Almasy, L.; Bierut, L. J.; Bucholz, K. K.; Goate, A.; Aliev, F.; Dick, D.; Hesselbrock, V.; Hinrichs, A.; Kramer, J.; Kuperman, S.; Nurnberger, J. I., Jr.; Rice, J. P.; Schuckit, M. A.; Taylor, R.; Todd, W. B.; Tischfield, J. A.; Porjesz, B.; Foroud, T. Genomewide association study of alcohol dependence implicates a region on chromosome 11. Alcohol Clin. Exp. Res., 2010, 34(5), 840-852.

[106] Zondervan, K. T.; Cardon, L. R. Designing candidate gene and genome-wide case-control association studies. Nat. Protoc., 2007, 2(10), 2492-2501. 
[107] Altshuler, D.; Daly, M. Guilt beyond a reasonable doubt. Nat. Genet., 2007, 39(7), 813-815.

[108] Schork, N. J.; Murray, S. S.; Frazer, K. A.; Topol, E. J. Common vs. rare allele hypotheses for complex diseases. Curr. Opin. Genet. Dev., 2009, 19(3), 212-219.

[109] Johnson, B. A.; Seneviratne, C.; Wang, X. Q.; Ait-Daoud, N.; Li, M. D. Determination of genotype combinations that can predict the outcome of the treatment of alcohol dependence using the 5-HT(3) antagonist ondansetron. Am. J. Psychiatry, 2013, 170(9), 10201031.

[110] Kranzler, H. R.; Armeli, S.; Tennen, H.; Covault, J.; Feinn, R.; Arias, A. J.; Pettinati, H.; Oncken, C. A double-blind, randomized trial of sertraline for alcohol dependence: moderation by age of onset [corrected] and 5-hydroxytryptamine transporter-linked promoter region genotype. J. Clin. Psychopharmacol., 2011, 31(1), 22-30.

[111] Kranzler, H. R.; Armeli, S.; Tennen, H. Post-treatment outcomes in a double-blind, randomized trial of sertraline for alcohol dependence. Alcohol Clin. Exp. Res., 2012, 36(4), 739-744.

[112] Tidey, J. W.; Monti, P. M.; Rohsenow, D. J.; Gwaltney, C. J.; Miranda, R., Jr.; McGeary, J. E.; MacKillop, J.; Swift, R. M.; Abrams, D. B.; Shiffman, S.; Paty, J. A. Moderators of naltrexone's effects on drinking, urge, and alcohol effects in non-treatmentseeking heavy drinkers in the natural environment. Alcohol Clin. Exp. Res., 2008, 32(1), 58-66.

[113] Hutchison, K. E.; Ray, L.; Sandman, E.; Rutter, M. C.; Peters, A.; Davidson, D.; Swift, R. The effect of olanzapine on craving and alcohol consumption. Neuropsychopharmacology, 2006, 31(6), 1310-1317.
[114] Ray, L. A.; Chin, P. F.; Miotto, K. Naltrexone for the treatment of alcoholism: clinical findings, mechanisms of action, and pharmacogenetics. CNS. Neurol. Disord. Drug Targets., 2010, 9(1), 13-22.

[115] Oslin, D. W.; Berrettini, W.; Kranzler, H. R.; Pettinati, H. Gelernter, J.; Volpicelli, J. R.; O'Brien, C. P. A functional polymorphism of the mu-opioid receptor gene is associated with naltrexone response in alcohol-dependent patients. Neuropsychopharmacology, 2003, 28(8), 1546-1552.

[116] Anton, R. F.; Oroszi, G.; O'Malley, S.; Couper, D.; Swift, R.; Pettinati, H.; Goldman, D. An evaluation of mu-opioid receptor (OPRM1) as a predictor of naltrexone response in the treatment of alcohol dependence: results from the Combined Pharmacotherapies and Behavioral Interventions for Alcohol Dependence (COMBINE) study. Arch. Gen. Psychiatry, 2008, 65(2), 135-144.

[117] Gelernter, J.; Gueorguieva, R.; Kranzler, H. R.; Zhang, H.; Cramer, J.; Rosenheck, R.; Krystal, J. H. Opioid receptor gene (OPRM1, OPRK1, and OPRD1) variants and response to naltrexone treatment for alcohol dependence: results from the VA Cooperative Study. Alcohol Clin. Exp. Res., 2007, 31(4), 555-563.

[118] Ray, L. A.; Hutchison, K. E. Effects of naltrexone on alcohol sensitivity and genetic moderators of medication response: a double-blind placebo-controlled study. Arch. Gen. Psychiatry, 2007, 64(9), 1069-1077.

[119] Chamorro, A. J.; Marcos, M.; Miron-Canelo, J. A.; Pastor, I. Gonzalez-Sarmiento, R.; Laso, F. J. Association of micro-opioid receptor (OPRM1) gene polymorphism with response to naltrexone in alcohol dependence: a systematic review and meta-analysis. Addict. Biol., 2012, 17(3), 505-512. 